\title{
Influence of Clay Minerals on Some Soil Fertility Attributes: A Review
}

\author{
Georges Kogge Kome* ${ }^{*}$, Roger Kogge Enang, Fritz Oben Tabi, \\ Bernard Palmer Kfuban Yerima \\ Department of Soil Science, Faculty of Agronomy and Agricultural Sciences, University of Dschang, Dschang, Republic of \\ Cameroon \\ Email: ${ }^{\star}$ komegeo@yahoo.fr
}

How to cite this paper: Kome, G.K., Enang, R.K., Tabi, F.O. and Yerima, B.P.K. (2019) Influence of Clay Minerals on Some Soil Fertility Attributes: A Review. Open Journal of Soil Science, 9, 155-188. https://doi.org/10.4236/ojss.2019.99010

Received: June 10, 2019

Accepted: September 22, 2019

Published: September 25, 2019

Copyright (c) 2019 by author(s) and Scientific Research Publishing Inc. This work is licensed under the Creative Commons Attribution International License (CC BY 4.0).

http://creativecommons.org/licenses/by/4.0/

\begin{abstract}
Clay minerals constitute an important component of the soil system and knowledge of their role in soil fertility is imperative for sustainable soil management and productivity. The aim of this work is to overview the influence of clay minerals on some major soil fertility attributes. The rationale for carrying out this work is that most soil fertility studies rarely incorporate soil mineralogy. Clay minerals, through their physical and chemical properties, affect soil fertility by controlling nutrient supplies and availability, through the sequestration and stabilization of soil organic matter, by controlling soil physical properties through microaggregate formation, by influencing soil acidity and controlling soil microbial population and activity. The main processes involved in these relationships are dissolution-precipitation and adsorption-desorption processes, alongside mechanisms involving the formation of short-range-ordered phases. Although the determination of soil mineralogical properties is very costly and time-consuming, information about a soil's mineralogy is imperative for a holistic understanding and proper management of soil fertility. Therefore, the development of rapid, low-cost, reliable and efficient techniques of soil mineralogical analysis, directly applicable to soil fertility investigations, constitutes a major challenge. Also, future research should investigate the relationships between clay minerals and soil nitrogen vis-à-vis sequestration and stabilization. Lastly, clay minerals should be considered in studies dealing with soil quality assessment, especially in the choice of soil quality indicators.
\end{abstract}

\section{Keywords}

Clay Mineralogy, Nutrient Supply, Ion Adsorption-Desorption, Mineral Dissolution-Precipitation, Nutrient Availability 


\section{Introduction}

Soil fertility is defined as "the quality of a soil that enables it to provide nutrients in adequate amounts and in proper balance for the growth of specific plants or crops" [1]. Soil fertility combines several soil properties including chemical, physical, biological and mineralogical, all of which affect directly or indirectly nutrient dynamics and availability [2]. Soil mineralogical properties appear to have a significant role in soil fertility management [3] but seem to be ignored in most studies, even in fertilizer recommendations [4], especially in Africa [5].

Clay minerals are naturally inorganic compounds with definite physical, chemical and crystalline properties and are classified as primary or secondary, silicates or non-silicates and crystalline or amorphous [6]. Primary minerals form at elevated temperatures and pressures, and are usually derived from igneous or metamorphic rocks, while secondary minerals are the culmination of either alteration of the primary mineral structure or neoformation through precipitation or recrystallization of dissolved constituents into a more stable structure [7] [8]. Common primary minerals in soil environments include silicates, oxides of $\mathrm{Fe}$ and $\mathrm{Al}, \mathrm{Zr}$ and $\mathrm{Ti}$, and phosphates, while typical secondary minerals found in soil environments include alumino-silicates, oxides and hydroxides, carbonates, sulphates and amorphous minerals [6]. Secondary minerals are mainly found in the clay-sized and fine-silt-sized fractions, and form the most reactive inorganic materials in soils [9], thereby influencing availability of nutrient elements through various mechanisms. Soil clay minerals are grouped into 1:1 and 2:1 clay minerals, depending on the ratio of silica tetrahedral sheet to alumina octahedral sheet. The 1:1 clay minerals, primarily kaolinite, are found in most soils, but predominate in highly weathered soils of humid tropical regions. In tropical environments, sesquioxide minerals rich in $\mathrm{Fe}$ and $\mathrm{Al}$ dominate. The 2:1 swelling or expandable clays include the smectite and vermiculite groups, which have large surface areas and high cation exchange capacities (CEC). These clay minerals play a significant role in dictating the suitability and behaviour of soil for various land uses. Clay mineralogy-soil fertility relationship is an imperative component in understanding and managing soil fertility for sustaining crop production, especially in the tropics [10] [11].

Clay mineralogy appears to be one of the most important indicators of soil quality [12], and proper knowledge of the clay mineralogy of a soil has significant practical implications on the use of fertilizers, on application and management [13] [14] [15] [16], and on the bioavailability of heavy metals in soil [17]. Furthermore, soil mineralogy-soil fertility relationship is a basic component in understanding and interpreting the results of fertility experiments and soil analytical data, especially in developing fertilizer recommendation systems [18] [19] [20]. Unfortunately, many soil fertility studies have hardly considered the role of soil mineralogy in understanding soil fertility and nutrient dynamics in agro ecosystems [21]. The lack of integrated soil mineralogy-soil fertility studies is indicated by the lack of interest by soil fertility researchers in carrying out detailed 
soil mineralogical studies [22] and also the tedious processes involved in characterization, identification and quantification of clay minerals. Another reason is the lack of inexpensive and rapid spectroscopic techniques for soil characterization, especially in developing countries [23]. Notwithstanding, a holistic understanding of soil fertility management must incorporate soil mineralogy since it has often been inferred that knowledge of the properties of these reactive materials should enable close predictions of the useful soil properties, whether for growing plants, or for other purposes [9]. According to Karathanasis [24], the effect of the soil mineralogical composition on soil productivity is two-fold; 1) it influences chemical reactions regulating nutrient availability and uptake and 2) it affects physical properties controlling soil moisture balance and physical conditions of the soil. In order to make visible the link that exists between clay minerals and soil fertility, a summary is presented on the influence of clay minerals on nutrient supply and availability, the role of clay minerals on soil organic matter retention, the relationship between soil mineralogy and soil physical properties, the relationship between soil mineralogy and soil acidification, and the influence of clay minerals on soil microbial activity.

In this review, we consider two important properties of clay minerals capable of influencing soil fertility. The chemical property considered is the cation exchange capacity and the physical property considered is the surface area. We focus on the direct influence of the physicochemical properties of clay minerals on the physical, chemical and biological properties of soil and also on the direct and indirect influence of clay minerals on nutrient availability. Due to the large number of publications relating soil mineralogy and different soil properties, we cannot give an exhaustive overview of all the works-rather, we focus on the most relevant ones that directly relate to soil fertility and plant growth, thereby making a synthesis of both earlier studies and recent ones.

\section{Role of Clay Minerals in the Supply and Availability of Plant Nutrients}

Of the three major soil components (solid, liquid and gas), the solid fraction is constituted by soil minerals and organic matter, which exert significant direct and indirect influences on the supply and availability of most nutrient elements [25] [26] [27]. The main processes involved in the release and fixation of nutrient elements in soils include dissolution-precipitation and adsorption-desorption. Soil minerals therefore act both as sources and sinks of essential plant nutrients. Of the seventeen elements considered as being essential for plants, most (N, P, K, Ca, Mg, S, B, Cl, Mn, Fe, Zn, Cu, Mo and Ni) are derived from the soil solution while few others are derived from water $(\mathrm{O}$ and $\mathrm{H})$ and air $(\mathrm{N}, \mathrm{C}, \mathrm{O})[28]$. Through the weathering of primary minerals, plant nutrients are released into the soil solution. These weatherable primary minerals act as an important reservoir for these elements. Micas and illite are the most important sources of $\mathrm{K}$ in many soils [29] and they also contain $\mathrm{Mg}, \mathrm{Fe}, \mathrm{Ca}, \mathrm{Na}, \mathrm{Si}$, and a number of micronutrients. Significant amounts of $\mathrm{Ca}, \mathrm{Si}$ and smaller amounts of 
$\mathrm{Cu}$ and $\mathrm{Mn}$ are present in feldspars. Amphiboles and pyroxenes are vital reservoirs of $\mathrm{Mg}, \mathrm{Fe}, \mathrm{Ca}, \mathrm{Si}$, and most of the micronutrients. Although the weathering rates of primary minerals for certain elements may not be fast enough to meet plant nutrient requirements on a short-term basis, particularly in managed cropping systems, mineral weathering is an important and long-term source of several geochemically derived nutrients [6].

Generally, the available nutrient supply in soils is considered to be the sum of both soluble and exchangeable forms. The capacity of the soil to replenish the solution nutrient concentration after it has been lowered, e.g. by plant nutrient uptake, leaching, fixation, depends on the mineralogical composition of the soil. This is because a great portion of the cation exchange capacity of the soil, which determines the ability of the soil to supply growing plants with nutrients, is related to crystalline and amorphous mineral components. The magnitude of the ion exchange reaction is determined by the type of ions involved, nature of the soil solution and the strength of attraction between a particular mineral and a specific cation [24]. Adsorption reactions involving minerals are often more important in controlling plant nutrient element availability than the release of nutrient elements by mineral weathering. Phyllosilicates with a permanent charge (e.g. vermiculite and smectite) offer exchange sites that hold a number of essential nutrients in their cationic form (cation exchange capacity), such as $\mathrm{Ca}^{2+}, \mathrm{Mg}^{2+}, \mathrm{K}^{+}$, and $\mathrm{Na}^{+}$[30]. The nutrients are retained by outer-sphere complex formation and may be taken up by plant roots through diffusion and mass-flow transfer processes [31] [32]. On the other hand, variable charge minerals with low CEC/AEC and low crystallinity (e.g. Fe oxides) often have higher affinity for anions (e.g, $\mathrm{H}_{2} \mathrm{PO}_{4}^{-}, \mathrm{NO}_{3}^{-}$), especially under acid $\mathrm{pH}$ conditions [33] [34].

Figure 1 summarizes the role of clay minerals in the release and availability of soil nutrients. As indicated in the figure, not all the added nutrients from fertilizers, for example, will be available for the plants. Apart from the well-known losses through leaching and volatilization, clay minerals can readily adsorb the added nutrients from fertilizers and render them stable and non-exchangeable. Thus, knowledge of the type and quantity of clay minerals is important for fertilizer application and use efficiency. However, the adsorbed nutrients can become available if appropriate management (e.g. soil $\mathrm{pH}$ amelioration) is carried out so as to create a conducive environment that can enhance nutrient desorption.

Figure 1 further shows that clay minerals control nutrient availability through the influence of physical, chemical and biological processes involved in nutrient release and cycling (desorption, dissolution, mineralization, adsorption, precipitation, and immobilization). There is also an intrinsic link between clay minerals and the labile and non-labile nutrient pools.

\subsection{Role of Clay Minerals on Nitrogen, Phosphorus and Potassium Availability}

In general, the bulk of plant available nitrogen in soil comes from mineralization 


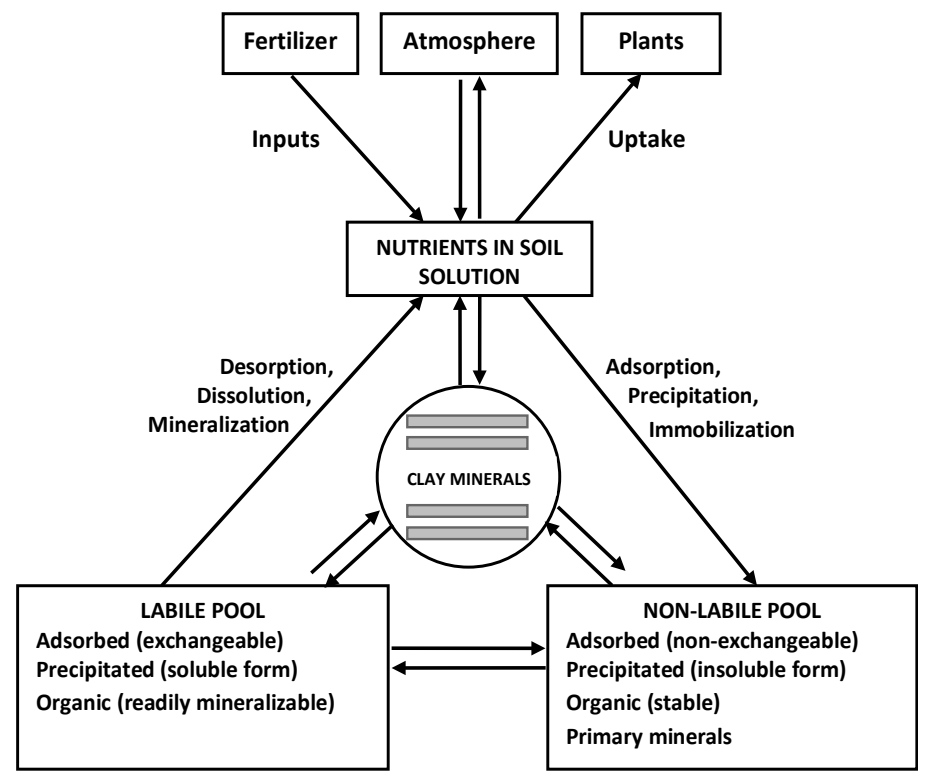

Figure 1. Role of clay minerals on nutrient supply and availability. Source: Adapted from Delgado and Gomez [35].

of soil organic matter [36]. There is also a large amount of soil nitrogen that derives from the weathering of nitrogen-bearing parent materials such as $\mathrm{mi}$ ca-schists [37] and nitrogen-rich siliciclastic rocks [38] [39] [40] [41] [42]. Nitrogen from the soil solution is usually taken up by plants in the form of nitrate $\left(\mathrm{NO}_{3}^{-}\right)$and exchangeable ammonium $\left(\mathrm{NH}_{4}^{+}\right)$ions. In soils dominated by variable surface charge minerals (kaolinite and $\mathrm{Fe}$ and $\mathrm{Al}$ oxides) such as Oxisols and Ultisols, the capacity to retain large amounts of $\mathrm{NO}_{3}^{-} \mathrm{N}$, particularly in the subsoil horizons is evident. For example, Lehmann et al. [43] observed 150 - 300 $\mathrm{kg} \cdot \mathrm{ha}^{-1} \mathrm{NO}_{3}^{-} \mathrm{N}$ in a Brazilian Oxisol up to a depth of about $2 \mathrm{~m}$. Rasiah and Armour [44] equally estimated between $17-32 \mathrm{t} \cdot \mathrm{ha}^{-1} \quad \mathrm{NO}_{3}^{-} \mathrm{N}$ to a depth of 10 $\mathrm{m}$ under different land uses in Oxisols from northern Queensland in Australia. The large adsorption of $\mathrm{NO}_{3}^{-}-\mathrm{N}$ was due to the high anion exchange capacity (AEC) of the soils. Under laboratory conditions using batch experiments, Kothawala and Moore [45] observed that different forest soils (including Podzols, Brunisols, Luvisols, Gleysols, and an organic soil) from Canada showed different degrees of dissolved nitrogen adsorption $\left(\mathrm{NH}_{4}^{+}\right.$and $\mathrm{NO}_{3}^{-}$) due to differences in their mineralogical compositions. The adsorbed nitrogen in soil by clay minerals is a major contributing factor to soil $\mathrm{N}$ depletion and loses, especially in subsoil horizons where the type of minerals favour their retention [43] [46]. Many studies have also reported the presence of nitrogen in various bed rock types ranging from $0.1-1050 \mathrm{mg} \cdot \mathrm{Kg}^{-1} \mathrm{~N}$ in igneous and granitic rocks and $>1000 \mathrm{mg} \cdot \mathrm{Kg}^{-1} \mathrm{~N}$ in some sedimentary rocks [47]. Thus, such adsorbed nitrate is likely inaccessible to most field crops because it is found at great depths. Fixation and defixation of $\mathrm{NH}_{4}^{+}$in soil is highly dependent on clay mineral composition [14] [47] [48]. In contrast to highly weathered oxisols and ultisols with variable charge minerals, soils with permanent charge minerals and high 
cation exchange capacity (e.g, smectite, vermiculite, illite and interstratified minerals with 2:1 layers) have the ability to retain ammonium $\left(\mathrm{NH}_{4}^{+}\right)$ions. $\mathrm{A}$ large proportion of the $\mathrm{NH}_{4}^{+}$Nitrogen is retained in the interlayers of 2:1 phyllosilicates and is not readily exchangeable [49]. The process of $\mathrm{NH}_{4}^{+}$fixation is similar to that of $\mathrm{K}^{+}$fixation due to similarity in ionic sizes and valence properties, and therefore competes for the same non-exchangeable sites of 2:1 clay minerals [47] [48]. Thus, the presence of $\mathrm{K}^{+}$in soil (from K-bearing minerals) greatly influences plant nitrogen (in the form of $\mathrm{NH}_{4}^{+}$) availability especially when it is applied in the form of ammonium $\mathrm{N}$-fertilizers such as ammonium sulphate $\left(\left(\mathrm{NH}_{4}\right)_{2} \mathrm{SO}_{4}\right)$ and ammonium nitrate $\left(\mathrm{NH}_{4} \mathrm{NO}_{3}\right)$ [14]. Therefore, field experiments aimed at investigating crop response to $\mathrm{N}$-bearing fertilizers necessitate complementary soil mineralogical investigations for a better interpretation of experimental results. With the exception of sandy soils, the amount of fixed $\mathrm{NH}_{4}^{+}$in the soil ranges from about $350-3800 \mathrm{~kg} \cdot \mathrm{ha}^{-1} \mathrm{NH}_{4}^{+}-\mathrm{N}$ in the top $30 \mathrm{~cm}$ of soil; vermiculite and partially weathered illite generally have a greater capacity to fix $\mathrm{NH}_{4}^{+}$in soils than the smectite group of minerals [48] [50]. The behavior and capacity of 2:1 phyllosilicates in fixing $\mathrm{NH}_{4}^{+}$ions is related to the magnitude and origin of negative charge in these minerals. $\mathrm{NH}_{4}^{+}$ -fixation generally increases with the increasing amount of layer charge in the 2:1 phyllosilicates. In earlier studies, Sahrawat [51] observed that $\mathrm{NH}_{4}^{+}$fixing capacity of 12 tropical rice soils was neither related to soil $\mathrm{pH}, \mathrm{SOM}$ nor clay content but rather to the amount of active iron in the soils due to the reversible redox behavior of iron oxides in the soils. Equally, Gouveia and Eudoxi [52] found that $\mathrm{NH}_{4}^{+}$fixation was significantly related to soil type (where soils with illitic minerals showed the highest fixation) but contrary to the observations of Sahrawat [51], the fixed amount of $\mathrm{NH}_{4}^{+}$was related to clay content, soil $\mathrm{pH}$ and SOM.

Phosphorus is primarily taken up by plants in the form of orthophosphates (either as $\mathrm{HPO}_{4}^{2-}$ or $\mathrm{HPO}_{4}^{-}$) depending on the $\mathrm{pH}$ of the soil medium [53] [54]. The concentration of $\mathrm{P}$ in soil water is generally very low $(<0.01 \%$ of the total soil $\mathrm{P}$ ), with the bulk of the soil $\mathrm{P}$ existing as organic $\mathrm{P}$, insoluble compounds of $\mathrm{P}$ with $\mathrm{Al}, \mathrm{Fe}$, and $\mathrm{Ca}$, and phosphate adsorbed to $\mathrm{Fe}$ and $\mathrm{Al}$ oxides and phyllosilicates [50]. Generally, the sorption of phosphates is affected by the type and nature of the reactive sites of clay minerals. Oxides and hydroxides of $\mathrm{Fe}$ and $\mathrm{Al}$ such as hematite, goethite and gibbsite are species primarily responsible for the adsorption of large quantities of phosphates [54] [55]. The availability of phosphate ions for plant uptake is greatly dependent on reactions with clay minerals through adsorption and precipitation processes [54]. In the specific case of volcanic soils, alumino-silicate minerals such as allophane, imogolite and Fe- and Al-oxides retain huge quantities of soil organic phosphorus [56] through various mechanisms involving association with humic substances and expandable phyllosilicates [56] [57]. According to Stutter et al. [58], the phosphorus retained in the lattices of these minerals is protected from microbial and enzymatic decomposition, making it deficient for plant uptake. However, other studies have shown that microorganisms are capable of converting soil $\mathrm{P}$ (fixed) to 
plant-available orthophosphate through a three-step process [59] These processes are: 1) $\mathrm{P}$ bound in mineral and organic matter complexes is solubilized by plant or microbial organic anions and acids, 2) solubilized organic $\mathrm{P}$ is mineralized by phosphatases to release orthophosphate, and 3) both solubilization and mineralization processes occur proximal to the plant root.

The most important potassium-bearing minerals in soils are alkali feldspars (20 to $30 \mathrm{~g} \cdot \mathrm{kg}^{-1} \mathrm{~K}$ ), muscovite ( $\mathrm{K}$ mica, 60 to $90 \mathrm{~g} \cdot \mathrm{kg}^{-1} \mathrm{~K}$ ), biotite ( $\mathrm{Mg}$ mica, 36 to $80 \mathrm{~g} \cdot \mathrm{kg}^{-1} \mathrm{~K}$ ), and illite (32 to $56 \mathrm{~g} \cdot \mathrm{kg}^{-1} \mathrm{~K}$ ) [32] [60] [61] and total soil $\mathrm{K}$ concentration typically ranges from $0.2 \%$ to $3.3 \%$ of the total soil mass [32] [61]. These are the main natural potassium sources from which $\mathrm{K}^{+}$is released by weathering. In natural soils, potassium is derived ultimately from the potassium silicate minerals with over $90 \%-95 \%$ of $\mathrm{K}$ existing in the structure of these minerals [13] [32] [62]. In deeply weathered, highly oxidized soils that have low organic matter, it is essentially the clay minerals that are responsible for the release of exchangeable $\mathrm{K}$ that is measured in soil analysis [19] [29] [63]. Under these humid conditions, soils become acidic, thereby promoting the formation of chlorite from $\mathrm{K}^{+}$-selective 2:1 minerals. Thus, soils developed under humid conditions have a poor $\mathrm{K}^{+}$-selective binding capacity and are low in potassium [60]. During the alteration of micas (biotite and muscovite), $\mathrm{K}^{+}$is replaced by hydrated cations such as $\mathrm{Mg}^{2+}$ or $\mathrm{Ca}^{2+}$, thus rendering it available for plants [9]. A combination of soil mineralogy, physicochemical properties and soil moisture regime gives a better insight into the effects of clay minerals on different forms of $\mathrm{K}$ in soil [64] [65] [66]. Raheb and Heidari [65] observed that non-exchangeable potassium in smectite-dominant soils was lower than those dominated by vermiculite, hydroxy-interlayered vermiculite and illite, and there were significant correlations between exchangeable potassium and clay content, organic carbon and cation exchange capacity. Similarly, Bajwa [64] observed that beidelitic clays can fix $>80 \%$ of $\mathrm{K}$ under aquic soil conditions. In another study to investigate the kinetics of non-exchangeable $\mathrm{K}$ release as a function of soil mineralogy and soil type, it was observed that the rate of $\mathrm{K}$ release was greater in soils dominated by expansible clay minerals, notably smectites and vermiculite, compared to soils dominated by chlorite, palygorskite and illite [67]. In addition to type of clay mineral, it has been reported that $\mathrm{K}$ fixation capacity of calcareous soils correlated strongly with clay content and CEC [68]. Thus, it is very important to evaluate the effects of vermiculitic and illitic soils on the application of $\mathrm{NH}_{4}^{+}$and $\mathrm{K}^{+}$-based fertilizers and nutrient use efficiency of crops. A recent investigation showed that the uptake of $\mathrm{K}$ by plants was as a function of the amount of $\mathrm{K}$ released from the clay mineral, and the amount of $\mathrm{K}$ released or adsorbed (in the case of fertilization) was highly dependent on the mineralogical composition of the clay mineral [66].

\subsection{Role of Clay Minerals on Availability of Micronutrients (B, Cl, Mn, Fe, Zn, Cu, Mo, Ni)}

Among the micronutrients needed by plants, $\mathrm{Fe}, \mathrm{Mn}, \mathrm{Cu}, \mathrm{Zn}$, and $\mathrm{Ni}$ are taken 
up in their cationic forms, while $\mathrm{B}, \mathrm{Mo}$, and $\mathrm{Cl}$ are taken up in their anionic forms. Copper is most abundant in mafic (rich in $\mathrm{Mg}, \mathrm{Ca}, \mathrm{Na}$, and $\mathrm{Fe}$, commonly basalt and gabbro) rocks, with concentrations ranging from 60 to $120 \mathrm{mg} \cdot \mathrm{kg}^{-1}$ $\mathrm{Cu}$. High Zn concentrations (about $95-100 \mathrm{mg} \cdot \mathrm{g}^{-1} \mathrm{~K}$ ) are derived from basaltic igneous rocks and shale; one of the five major pools of zinc in soil is primary minerals and secondary alumino-silicate materials [69]. In soils, iron is mainly present in the insoluble $\mathrm{Fe}^{3+}$ form, but other forms exist depending on the $\mathrm{pH}$ and moisture conditions of the soil. It occurs as Fe (III) oxides and constitutes the major components of some highly weathered mineral soils (Oxisols) with very low CEC. Nickel is primarily derived from soils developed on basic igneous rocks with concentrations ranging from 2000 to $6000 \mathrm{mg} \cdot \mathrm{kg}^{-1} \mathrm{Ni}$ [70].

Most of the available boron in soil is believed to be derived from marine sediments as evaporates by chemical precipitation and include borax, colemanite, ulexite, inyoite, and inderite [71]. These boron minerals are made up of hydrated calcium, magnesium, and sodium boron minerals. In most of the well-drained soils formed from acid rocks and metamorphic sediments, the most common boron-containing mineral is tourmaline [71] [72]. In neutral or acidic soils, the dominant boron form is the neutral molecule $\mathrm{B}(\mathrm{OH})_{3}$ (boric acid), while in alkaline soils, significant amounts of boron occur in the form of the borate anions (either $\mathrm{B}(\mathrm{OH})_{4}^{-}$or $\mathrm{BO}_{3}^{3-}$ ) [71]. Considering the neutral molecule $\mathrm{B}(\mathrm{OH})_{3}$, boron stands as the only essential element taken up by plants in the form of a neutral (uncharged) molecule. Soil texture has been reported to affect B availability in soils, owing to the clay minerals present in soil. Gupta [72] observed that B deficiency is higher in coarse-textured soils than in fine-textured soils due to the high leaching of boron in sandy soils. Since boron has a coordination number of four, soils rich in phyllosilicate minerals such as phlogopite, saponite, illite and montmorillonite, harbour boron in their lattices where they substitute for tetrahedral silicon and aluminium [71].

Soil parent materials with the highest concentrations of molybdenum include phosphorite, shale, limestone, and sandstone [73], and the available molybdenum content generally increases with increase in alkalinity or fineness of the soil texture [74]. Mineral forms of molybdenum commonly present in soils include molybdenite $\left(\mathrm{MoS}_{2}\right)$, powellite $\left(\mathrm{CaMoO}_{4}\right)$, wulfenite $\left(\mathrm{PbMoO}_{4}\right)$, ferrimolybdite $\left(\mathrm{Fe}_{2}\left(\mathrm{MoO}_{4}\right)\right.$ ), ilsemanite (molybdenum oxysulfate), and jordisite (amorphous molybdenum disulphide) [73] [75]. Under low pH conditions, Mo is readily adsorbed in soil by $\mathrm{Fe}$ and $\mathrm{Al}$ oxides, kaolinite, illite and montmorillonite [76].

Manganese is most abundant in soils developed from rocks rich in iron owing to its association with this element. Adsorption reactions play little role in controlling the availability of Fe and Mn in soils. Rather, oxidation and precipitation reactions predominantly control the soil solution concentration of $\mathrm{Fe}$ and $\mathrm{Mn}$ [77] [78]. Goethite, hematite, and ferrihydrite are the most commonly occurring secondary Fe oxides in soils. Due to the microcrystalline size of Fe oxides, these minerals possess high specific surface areas and provide numerous adsorption 
sites for both cationic and anionic elements in almost all soil types. The two most stable $\mathrm{Fe}$ oxides, goethite and hematite, are known to have substantial structural substitution of trace elements, including $\mathrm{Mn}, \mathrm{Ni}, \mathrm{Zn}$, and $\mathrm{Cu}$ [79]. Kumar and Babel [80] observed that availability of $\mathrm{Cu}$ and $\mathrm{Zn}$ increased significantly ( $\mathrm{p}<0.05$ ) with increase in finer soil fractions (silt and clay) but decreased in soils having high $\mathrm{CaCO}_{3}$ contents. This observation can be explained by the increased solubility of $\mathrm{Cu}$ and $\mathrm{Zn}$ under acidic conditions $(\mathrm{pH}<5.5)$ compared to alkaline conditions $(\mathrm{pH}>7)$. The increased solubility of these elements may lead to toxicity.

Copper in soil is present as sulfide minerals, stable oxides, silicates, sulphates and carbonates [81]. The most abundant copper-containing mineral is charcopyrite $\left(\mathrm{CuFeS}_{2}\right)$. The concentration of copper ions in soils varies from 6 to 60 $\mathrm{mg} \cdot \mathrm{Kg}^{-1}$ [82]. The availability of copper in soil is controlled by reduction-oxidation conditions which can be affected by many factors such as water logging and compaction [78]. Additionally, increased solubility of $\mathrm{Cu}$ is favoured by acidic conditions $(\mathrm{pH}<5.5)$, which might lead to toxicity. Generally, adsorption and desorption of $\mathrm{Cu}^{2+}$ in soils is affected by the proportion of variable-charge and permanent-charge minerals in soils [83] and also by the nature (type) of the soil mineral [84] [85] [86]. On the other hand, Zinc is associated with hydrous oxides and carbonates through adsorption, surface complex formations, ion exchange, incorporation into the crystal lattice, and co-precipitation [69]. Fe and Mn oxides are common mineral constituents in many soils and are important substrates for the retention of many macronutrients and micronutrients. $\mathrm{Cu}, \mathrm{Zn}$, and $\mathrm{Ni}$ are adsorbed by $\mathrm{Fe}$ and $\mathrm{Al}$ oxides by forming complexes at low solution concentrations. Generally, the adsorption of $\mathrm{Cu}^{2+}, \mathrm{Zn}^{2+}$, and $\mathrm{Ni}^{2+}$ occurs by complex formation on negatively charged surfaces of 2:1 phyllosilicates and through complex formation on kaolinite surfaces [79].

Boron and Mo are taken up by plants as $\mathrm{H}_{3} \mathrm{BO}_{3}$ and $\mathrm{MoO}_{4}^{2-}$ respectively. In a similar manner to $\mathrm{Zn}, \mathrm{Cu}$ and $\mathrm{Ni}$ retention, $\mathrm{MoO}_{4}^{2-}$ is strongly adsorbed by metal oxides. Chlorine is taken up by plants in the chloride $\left(\mathrm{Cl}^{-}\right)$form, and adsorption reactions involving $\mathrm{Cl}^{-}$ions are similar to those involving $\mathrm{NO}_{3}^{-}$ions. Chloride is not adsorbed by minerals at $\mathrm{pH}$ levels above 7.0 and is only weakly adsorbed in kaolinitic and oxidic soils that have positive charges under acid conditions [79].

\section{Role of Clay Minerals on Soil Organic Matter Retention and Stabilization}

Soil organic matter (SOM) is both a source and a sink of plant nutrients [87]; it is an ion exchange material; it promotes the formation of soil aggregates and thus influences soil physical properties and soil moisture; and it is an energy substrate for soil microbes and macrofauna [88] [89]. Approximately $80 \%$ of the organic carbon (OC) that is active in the terrestrial carbon cycle is stored in soils [90] [91]. The bulk of nitrogen-containing organic matter appears to be bonded 
chemically to clay minerals and protected physically in soil aggregates rather than existing as complex chemical molecules of plant and microbial residues [92]. This sequestration is achieved through various mechanisms which include the formation of clay-humic complexes, sorption of organic matter on clay particles, fixation of organic carbon in the crystal lattices of clays and the formation of organo-metallic compounds such as $\mathrm{Ca}, \mathrm{Fe}$ and $\mathrm{Al}$ humates through humification processes [93] [94] [95] [96]. These complexation and humification processes lead to the overall stabilization of SOM by clay minerals [95] [97] [98]. In the particular case of arable soils, SOM is primarily stored in fine-particle-size fractions [99] [100] [101] and stable SOM constituents are primarily related to the proportion and characteristics of these fine particles in soils [102]. However, the type and quantity of clay minerals in these soils play an important role in retaining the added organic $\mathrm{C}$ and $\mathrm{N}$ in soil [103] [104]. In this case, the SOM is retained through physicochemical stabilization and aggregate formation [105]-[110].

Generally, phyllosilicates such as smectites are more intimately associated with retaining and increasing SOM than the other clay minerals [91] [111] [112], mainly due to their high specific surface area and CEC [113], even though contrary observations have been reported [114] [115] [116]. Some other studies have shown that $\mathrm{Fe}$ and/or $\mathrm{Al}$ oxides can also have a large influence on the retention of OC in soil and usually are better adsorbents for OC than phyllosilicates [112] [117] [118]. This observation has been attributed to the abundance and hence the overall increase in surface area of these oxides [108] [117]. This observation is usually common in high altitude Oxisols where the rate of organic matter mineralization is reduced, due to lower temperatures. Allison [88] observed that under similar climatic conditions, OC contents in fine-textured (clayey) soils is about 2 to 4 times greater than in sandy soils, due to lower surface area in the latter, as well as higher mineralization associated to increased aeration. In contrast, Yerima and Van Ranst [119] reported that some coarse-textured soils such as andisols store huge quantities of $\mathrm{OM}$ than some fine-textured soils due to the formation of allophane-organic matter complexes inherent in such soils, an observation similar to that reported by Singh et al. [120].

Notwithstanding, this debate has been clarified by other studies. For example, Wagai and Mayer [121] observed strong correlations between iron oxides $\left(\mathrm{Fe}_{\mathrm{x}}\right.$ $\mathrm{O}_{\mathrm{y}}$ ) and organic matter in a wide variety of soils spanning 8 different orders from different parts of the world and concluded that high volumetric ratios of organic matter to $\mathrm{Fe}_{\mathrm{x}} \mathrm{O}_{\mathrm{y}}$ are due to organic matter stabilization through mechanisms involving organo-Fe complex formation or tertiary associations among $\mathrm{Fe}_{\mathrm{x}} \mathrm{O}_{\mathrm{y}}, \mathrm{OM}$ and other soil minerals, and not through the commonly reported sorption mechanisms found in the literature. Similarly, Singh et al. [120] observed that soil carbon stabilization was related more to the sesquioxides content than to the clay types or their relative specific surface areas. In a study on the relationship between different soil minerals (Illite, Smectite, Chlorite and Kaoli- 
nite) with SOC, Zeraatpische and Khormali [117] observed that illite and chlorite contents were significantly correlated with SOC, while smectite and kaolinite were not. This observation is explained by the fact that illite and chlorite develop high amphoteric properties in their ruptured edges, which absorb the OC [115]. Zeraatpische and Khormali [117] suggested that kaolinite showed the least correlation with SOC due to its small specific surface area. Contrary to the results of Zeraatpische and Khormali [116], Jindaluang et al. [112] analysed several mineralogically contrasting soils and observed that smectitic soils tend to have more OM content than kaolinitic ones. Schulten and Leinweber [122] have summarized a quantitative relationship between clay mineralogy and $\mathrm{OC}$ which can be used to deduce possible effects of clay mineralogy on the OC contents of organic-mineral clay fractions (Table 1).

Table 1. Clay contents, predominant clay minerals and OC contents of organic-mineral clay fractions.

\begin{tabular}{|c|c|c|c|}
\hline $\begin{array}{l}\text { Clay } \\
\text { content }(\%)\end{array}$ & $\begin{array}{l}\text { Predominant clay } \\
\text { minerals }\end{array}$ & $\begin{array}{l}\text { OC content } \\
(\%)\end{array}$ & Soil type \\
\hline 60 & Smectite & 2 & Calcareous Grumusol (Calcic Vertisol) \\
\hline 39 & Kaolinite and smectite & $1-2$ & Alluvial soil (Fluvents) \\
\hline 32 & Allophane & $13-14$ & Humic Allophane soil (Typic Dystrandept) \\
\hline 6 & Smectite, less vermiculite & & $\begin{array}{l}\text { Orthic Ferro-Humic Podzol (Orthic } \\
\text { Spodosol) }\end{array}$ \\
\hline 17 & $\begin{array}{l}\text { Chlorite (vermiculite, } \\
\text { illite) }\end{array}$ & 11 & Humic Eluviated Gleysol (Humaquepts) \\
\hline $3-15$ & Illite (vermiculite) & $4-16$ & $\begin{array}{l}\text { Typic Ustochrept, Udic Haplustalf, Dystric } \\
\text { Cryochrept, Typic Cryorthod, Typic } \\
\text { Dystrochrept, Haplic Cryohumod }\end{array}$ \\
\hline 8 & Smectite & 15 & Xeralfic Haplargid \\
\hline $17-18$ & Kaolinite & $2-3$ & Merredin Sandy Loam (Ustalfs) \\
\hline $8-45$ & Chlorite-mixed layers & $1-20$ & Haplohumult, Argixeroll, Durargid, Andept \\
\hline 45 & Smectite & 2 & Pelloxerert \\
\hline 17 & Kaolinite and illite & $2-6$ & Rhodoxeralf \\
\hline 45 & Smectite and illite & $7-9$ & Haploboroll \\
\hline 46 & Palygorskite & $3-7$ & Calciaquoll \\
\hline 69 & Smectite & $1-2$ & Dystric Gleysol (Tropaquepts) \\
\hline 8 & Illite, less smectite & $4-6$ & Orthic Greyzem (Orthic Mollisol) \\
\hline 9 & Chlorite-mixed layers & $8-11$ & Dystric Cambisol (Dystropepts) \\
\hline 9 & $\begin{array}{l}\text { Illite (quartz, feldspars, } \\
\text { smectite) }\end{array}$ & $8-9$ & Typical Hapludalf \\
\hline 2 & Smectite & $6-17$ & Haplic Albeluvisol (Typic Haplocryalfs) \\
\hline 28 & Smectite/vermiculite & $2-5$ & Typic Paludalf, Typic Hapludalf \\
\hline
\end{tabular}

Source: Adapted from [122]. For consistency of classification, soils classified in other systems other than the U.S. Soil Taxonomy have been classified according to the U.S. Soil Taxonomy (2003) based on their approximate correlations, as established by [119]. 
Table 1 shows that soil fractions rich in kaolinite contain small amounts of OC whereas chlorite-rich clay fractions contain large amounts of OC. This difference in SOC content is explained by the low $\mathrm{pH}$ in the chlorite-rich clay fractions which favours the formation of secondary chlorites and inhibits the decomposition of OM [122]. Additionally, it is observed that smectite-rich fractions contain $\mathrm{OC}$ contents within a wide range, with the largest values in soils poor in clay contents. According to Schulten and Leinweber [122], the adsorption capacity of different clay minerals for OM may vary, depending on factors such as clay content and mineralogy, chemical and biological soil properties, vegetation type (as major driver of carbon inputs to soil), and soil management (in terms of manuring or organic residue removal) among other factors. The different soil types in the table above account for the variations observed in clay content, organic carbon and type/quantity of clay minerals. Additionally, it has been shown that environmental factors such as temperature and moisture could affect the carbon protection capacity of various clay types in soil [120]. Recently, it has been shown that mechanisms favouring mineral availability in soil, and hence the formation of the so-called short-range-ordered phases, are the key regulators of soil C storage [123] [124].

\section{Influence of Clay Minerals on Soil Physical Properties}

Soil physical properties such as texture, structure, moisture content, pore size distribution, plasticity, shrink-swell potential, soil strength and erodibilty affect every aspect of soil fertility and productivity. Soil physical properties determine the ease of root penetration, water availability and the ease of water absorption by plants, the amount of oxygen and other gases in the soil, lateral and vertical movement of water through the soil, and nutrient cycling [125]. Most of these properties are influenced to a large extent by the mineralogical composition of the soil. Particle size distribution results from the physical degradation of soil minerals due to imperfect lattice energy distributions in the silicate layers causing strains in the mineral structure [24]. Soil strength, aggregation and plasticity are affected by the various attractive and repulsive forces exerted by the various minerals. The overall structure of the soil is the product of the arrangement and bonding of individual soil particles into aggregates caused by ionic, organic, water and clay mineral surface interactions [126]. According to Schulten and Leinweber [122], clay mineralogical properties that influence aggregation are surface area, CEC, charge density, dispersivity and expandability. Non-crystalline clay minerals, such as allophane and imogolite, have high surface areas, and highly variable and $\mathrm{pH}$-dependant charge properties that generally increase aggregation [127]. Non-expanding variable-charge crystalline clays, such as kaolinite (1:1), have low CEC and low surface area, which tend to decrease aggregate stability, while high activity clays such as smectites (Ca-smectites) and other 2:1 clays, which are associated with high CEC and large surface area, tend to increase aggregation [122]. It has been reported that the functional role of clay minerals in 
soil is the formation of microaggregates [110] [124] [128] [129] [130] [131] and these microaggregates greatly influence phosphorus adsorption and availability in soil [132] [133].

According to Nelson et al. [134], the interaction of clay mineralogical properties such as CEC and surface area with soil organic carbon influences soil dispersivity wherein less reactive clays, like kaolinite, are less dispersive, while high activity clays like smectites (Na-smectites) are highly dispersive. Soil water retention characteristics are also influenced by the clay mineralogical make-up of the soils [135], due to variations in specific surface area and solute-water-solid interactions of specific clay minerals. Soil erodibility is also affected by mineralogical composition because the mineralogy of the soil influences such properties as aggregate stability, permeability and soil shear strength [136] [137]. Ramezanpour et al. [62] observed that landscapes dominated by smectite group and double layer clay minerals that are dispersive (2:1 clays), such as Na-smectites, are more susceptible to soil loss by erosion, leading to the formation of gullies and badlands. Heshmati et al. [138] carried out a comparative study to evaluate the effects of soil and rock mineralogy on soil erosion and fertility status in Iran and observed that soils rich in calcite, dolomite, quartz and kaolinite were moderately resistant to erosion with the formation of inter-rill, rill and snow erosion, producing a moderate soil erosion intensity $\left(5-10 \mathrm{t} \cdot \mathrm{ha}^{-1} \cdot \mathrm{yr}^{-1}\right.$ of soil loss) whereas mica/smectite clay minerals produced gully erosion and considerable soil loss ( $>12.0 \mathrm{t} \cdot \mathrm{ha}^{-1} \cdot \mathrm{yr}^{-1}$ of soil). Equally, soils rich in smectite were found to promote landslide occurrences and severe annual soil loss $\left(>16 \mathrm{t} \cdot \mathrm{ha}^{-1} \cdot \mathrm{yr}^{-1}\right)$ [138].

Surface soil loss by erosion has been a major constraint to soil productivity in sub Saharan African countries. The direct effects of soil erosion on soil fertility status are reduction in topsoil thickness, alteration in soil properties, sedimentation and inundation of lowlands, and depletion of soil organic matter and nutrients. Additionally, eroded soils, with exposed sub-soil horizons, are prone to compaction because of high clay or gravel contents, and low organic matter contents. Hence, the exposed subsoil generally has higher bulk density and cone index, lower water infiltration rates, and higher runoff losses than uneroded soils. The resulting compacted soil alters soil tilth, limits root respiration and growth, and thus reduces crop production [32].

\section{Influence of Clay Minerals on Soil Acidification}

Soil acidity is one of the most important indices of soil health and almost all soil biochemical reactions are influenced by soil pH [139] [140] [141]. Soil acidity also conditions the activity, survival and growth of soil microorganisms [142]. With respect to soil fertility and crop production, clay minerals play an important role as they release various acidic species in the soil solution, which may significantly affect agricultural production [140] [141] [143] [144]. Acidic soils such as those of humid tropical environments generally have high concentrations of $\mathrm{Al}^{3+}$ and $\mathrm{H}^{+}$originating from either acidic soil minerals [145] [146] or 
acidic SOM [147] [148].

The natural acidification processes of these soils according to McBride [77] include: 1) removal of cations $\left(\mathrm{Ca}^{2+}, \mathrm{NH}_{4}^{+}, \mathrm{Mg}^{2+}, \mathrm{K}^{+}\right.$etc. $)$and anions $\left(\mathrm{PO}_{4}^{3-}\right.$, $\mathrm{NO}_{3}^{-}, \mathrm{SO}_{4}^{2-}$ etc.) from soil by plant roots; 2) metabolic activity of roots, microorganisms, and other living organisms in the soil-these metabolic processes generate $\mathrm{CO}_{2}$, soluble organic acids, and acidic organic residues, all of which behave as weak acids in the soil, displacing basic cations from exchange sites; 3 ) oxidation of reduced forms of $\mathrm{S}$ and $\mathrm{N}, 4)$ biological nitrification, and 5) dissolution of acidic gases from the atmosphere. Regarding the role of soil minerals on soil acidity, there exists a strong correlation between soil $\mathrm{pH}$ and $\mathrm{Al}^{3+}$ concentration.

Decreasing soil $\mathrm{pH}$ increases the instability of soil Al-minerals and thereby increases the concentration of total $\mathrm{Al}$ in solution [149]. These minerals are primarily $\mathrm{Al}$ oxides, gibbsite, feldspars, Al-rich allophanes, etc. When the $\mathrm{pH}$ is low $(<5.5)$ the concentration of $\mathrm{Al}^{3+}$ in soil solution can be influenced by several processes such as; 1) a decreasing amount of variable charge on exchange sites, 2) exchange of $\mathrm{Al}^{3+}$ with $\mathrm{H}^{+}, 3$ ) hydrolysis of $\mathrm{Al}$ with resulting increase in the concentration of $\left.\mathrm{Al}^{3+}, 4\right)$ dissolution of gibbsite and release of $\mathrm{Al}^{3+}$ [150]. Under advanced weathering conditions as is the case in most humid tropical soils, it is generally assumed that the activity of $\mathrm{Al}^{3+}$ is regulated by equilibrium with a gibbsite-like $\left(\mathrm{Al}(\mathrm{OH})_{3}\right)$ phase [150]. This solubility of $\mathrm{Al}$ depends on the solubility product $\left(\mathrm{K}_{\mathrm{sp}}\right)$. Considering the case of gibbsite, the solubility product can be expressed as follows [150]:

$$
\begin{gathered}
\mathrm{Al}[\mathrm{OH}]_{3(s)} \leftrightarrow \mathrm{Al}^{3+}+3 \mathrm{OH}^{-}, K_{\text {gibbsite }}=\left[\mathrm{Al}^{3+}\right]\left[\mathrm{OH}^{-}\right]^{3}=10^{-32.64} \\
\mathrm{Al}(\mathrm{OH})_{3(s)}+\mathrm{H}^{+} \leftrightarrow \mathrm{Al}^{3+}+3 \mathrm{OH}^{-}, K_{s p}=8.5
\end{gathered}
$$

Equation (1a) indicates that the activity of $\mathrm{Al}^{3+}$ in water depends on $\mathrm{pH}$ of the soil solution while Equation (1b) shows the dissolution of gibbsite in the presence of an acid or in acidic milieu. At pH values below 5.5, the concentration of $\mathrm{Al}^{3+}$ increases due to the increasing solubility of gibbsite [27]. Aluminium has a tendency to form hydroxy complexes, which can increase the solubility of gibbsite significantly. The total amount of dissolved $\mathrm{Al}$ in soil solution consists of both $\mathrm{Al}^{3+}$ ions and hydroxy complexes and can be described as a mass balance equation [77]:

$$
\mathrm{Al}_{\text {dissolved }}=\mathrm{Al}^{3+}+\mathrm{Al}(\mathrm{OH})^{2+}+\mathrm{Al}(\mathrm{OH})_{2}^{+}+\mathrm{Al}(\mathrm{OH})_{4}^{-}+\mathrm{Al}_{\text {complexes }}
$$

At $\mathrm{pH}$ values below 5.5, aluminosilicate clays and $\mathrm{Al}$ hydroxide minerals begin to dissolve, releasing $\mathrm{Al}$-hydroxy cations and $\mathrm{Al}^{3+}$ that then exchange other cations from soil colloids [77], especially the basic cations which are essential for plant nutrition such as $\mathrm{Ca}^{2+}, \mathrm{Mg}^{2+}$ and $\mathrm{K}^{+}$. The result is that the fraction of exchange sites occupied by $\mathrm{Al}^{3+}$ and its hydrolysis products can become large once the soil $\mathrm{pH}$ falls below 5.0, and the direct consequence of this high $\mathrm{Al}$ concentration in the soil solution is $\mathrm{Al}$ toxicity, which causes restricted growth of roots 
and stems, leading to increased susceptibility to drought and decreased use of subsoil nutrients [151] [152] [153]. Toxicity of Al becomes very pronounced at very low $\mathrm{pH}$ when it is present in the mononuclear $\mathrm{Al}^{3+}$ species which exists as an octahedral hexahydrate [154] [155]. According to Sanchez and Logan [156], about one third of tropical soils (an equivalence of 1.7 billion hectares) are acidic enough for soluble aluminium to be toxic for most plants. Apart from toxicity, high $\mathrm{Al}$ concentrations also render phosphorous unavailable for plant uptake [157] [158]. This is because similar to $\mathrm{Fe}, \mathrm{Al}$ becomes more accessible on cation exchange sites, in solution, or simply on exposed surfaces. Both ions react readily with phosphate, forming relatively insoluble compounds through the process of phosphate fixation [50] [158] [159].

$$
\mathrm{Al}^{3+}+3 \mathrm{H}_{2} \mathrm{PO}_{4}^{-} \leftrightarrow \mathrm{Al}\left(\mathrm{H}_{2} \mathrm{PO}_{4}\right)_{3}, \mathrm{pH}<5.5
$$

The product formed in Equation (3) is insoluble in water and precipitates from solution. With time, the Al-phosphate complex becomes less soluble and less available to plants. In the case where $\mathrm{Al}$ originates from a mineral such as Kaolinite, exposed Al-OH groups (or the octahedral $\mathrm{Al}$ ) react very fast with phosphates as follows [160]:

$$
\mathrm{Al}_{2} \mathrm{Si}_{2} \mathrm{O}_{5}(\mathrm{OH})_{4}+2 \mathrm{H}_{2} \mathrm{PO}_{4}^{-} \leftrightarrow 2 \mathrm{Al}(\mathrm{OH})_{2} \mathrm{H}_{2} \mathrm{PO}_{4}+\mathrm{Si}_{2} \mathrm{O}_{5}^{2-}
$$

Fixation of $\mathrm{Al}$ on cation exchange sites of soil colloids also means a reduction in cation exchange capacity. With respect to availability of soil nutrients, soil $\mathrm{pH}$ has great influence on plant nutrient availability, depending on the nature and behaviour of the nutrient element in different acidic media [161] [162]. Soil pH also affects biological activities of beneficial microorganisms such as bacteria, fungi and other soil microfauna [161]. Details of Al chemistry have been reviewed, where soil $\mathrm{Al}$ is reported to occur in many different forms as a function of soil $\mathrm{pH}$ [25] [27].

\section{Influence of Clay Minerals on the Activity and Population of Soil Microorganisms}

The activities of microorganisms in soil help to improve on its quality and fertility status [163] [164] [165] [166] [167], and hence the promotion of plant growth [168] [169] [170]. These organisms are imperative for maintaining the stability and productivity of agro-ecosystems [171]. In agricultural soils, these organisms play a role in the breakdown and mineralization of SOM, formation of humus, nutrient and elemental cycling, formation of soil aggregates, improvement of soil structure and water-holding capacity, biological nitrogen fixation, control of pests and diseases, climate regulation, promotion of plant growth and degradation of pollutants such as pesticides and hydrocarbons [172] [173] [174].

Soil microbial communities are greatly influenced and regulated by the environmental properties of their habitats. Soil $\mathrm{pH}$, moisture, and temperature have been reported as the primary factors affecting soil biotic activities, wherein spe- 
cific microorganisms have particular $\mathrm{pH}$, moisture and temperature optima that influence their activities [175]-[180]. Other factors affecting biological activity in natural soils include nature of substrates (energy rich or poor substrates), anthropogenic activities (tillage type), soil aeration, light availability, microbial associations, quantity and quality of SOM, microclimate conditions and soil physicochemical properties [181]. Additionally, the type of nutrient management (chemical fertilizers and organic amendments) in agricultural soils can either improve or degrade soil microbial communities [182] [183] [184] [185].

The correlation between particle size fractions and microbial populations in soil has been reported [186], but the role of clay minerals on soil biological activity has obtained little interest in soil fertility studies. Within the soil system, microorganisms can readily influence the properties of clay minerals and can also act as a living catalyst in the geochemical cycles of clay minerals [169] [187]. Regarding nutrient uptake by plants, microorganisms have different strategies to improve Fe uptake of plants, notably through the release of organic molecules and metabolites (e.g. phytosiderophores, organic acids and flavonoids which form complexes with $\mathrm{Fe}$ (III) thereby solubilizing the Fe found in soil minerals) [188]. Other important macronutrients in soil such as $\mathrm{K}$ can be made available to plants through the dissolution of silicate minerals by microorganisms such as Acidothiobacillus ferrooxidans, Paenibacillus spp, Bacillus mucilaginosus, $B$. edaphicus, and B. circulans through mechanisms such as acidolysis, complexolysis, chelation and exchange reactions [170]. As concerns K nutrition, much work has recently been conducted to reveal the role of microorganisms on $\mathrm{K}$ solubilization and availability for plant growth within the soil system [31] [189] [190]. With respect to $\mathrm{N}, \mathrm{P}, \mathrm{K}$ and micronutrients dissolution, availability and uptake by plants, Burghelea et al. [174] and Terrazas et al. [191] have reviewed the various mechanisms involved in soil-plant-microbiota interactions.

Through a variety of mechanisms such as reduction and oxidation of structural iron, mineral dissolution and precipitation, particular minerals with specific chemical compositions and properties may in turn influence microbial communities in soil [192] [193] [194] [195]. Ransom et al. [196] observed that the most common mineral-biological interaction in soil was the close association (surrounding) of isolated heterotrophic bacterial cells by clay minerals and that the external surfaces of the bacteria were covered with secreted exocellular slimes composed of cross-linked polysaccharide fibrils which act to bind mineral particles into relatively robust microaggregates (roughly $<25 \mu \mathrm{m}$ in diameter). In earlier studies, Filip (1973) reported the beneficial effects of bentonite on the growth of some soil microflora. Kostka et al. [197] demonstrated that pure cultures of Shewanella oneidensis strain MR-1 as well as enrichment cultures of Fe (III)-reducing bacteria from rice paddy soil and subsurface sediments are capable of conserving energy for growth with the structural Fe (III) bound in smectite clay as the sole electron acceptor. Their results showed that growth with smectitic Fe (III) is similar in magnitude to that with Fe (III) oxide minerals and 
is dependent upon the mineral surface area available, and thus concluded that Iron (III) bound in clay minerals acts as an important electron acceptor supporting the growth of bacteria in soils or sedimentary environments. Loveley and Phillips [198] also showed that microorganisms can completely oxidize organic compounds with Fe (III) or Mn (IV) as the sole electron acceptor and that oxidation of organic matter coupled with dissimilatory Fe (III) or Mn (IV) reduction can yield energy for microbial growth. Thus, the presence of Fe and Mn bearing minerals in soil serve as energy substrates for growth of some microorganisms. Stotzky and Rem [199] reported that the respiration of 27 fungal species was generally not affected by $\mathrm{pH}$ whereas the increase in concentration of montmorillonite $(>4 \%)$ significantly inhibited microbial respiration and promoted the growth of Bacillus subtilis, Bacillus megaterium, Proteus vulgaris and Pseudomonas sriata as a result of the buffering ability of this clay mineral to maintain the $\mathrm{pH}$ at levels adequate for sustained microbial growth. On the other hand, kaolinite played a similar role to montmorrilonite only at concentrations above $40 \%$, owing to the smaller specific surface and lower viscosity of koalinite compared to that of montmorillonite. It has also been observed that kaolinite and montmorillonite stimulate the exponential growth of Bacillus thuringiensis in a nutrient-rich medium due to the accumulation of nutrients on the surface of the clay particles through mechanisms of cation exchange and ligand bond processes [200]. Courvoisier and Dukan [201] investigated the effect of kaolinite on various growth parameters of Escherichia coli and observed that kaolinite significantly affected maximal growth rate and yield of the E. coli strain-(MG 1655 ) in minimum growth medium with $0.2 \%$ glucose, at an optimal concentration of 0.2 to $0.5 \mathrm{~g} / \mathrm{l}$. Carson et al. [202] also observed that the addition of minerals (such as mica) and rocks (such as basalt and rock phosphate) caused significant changes in the bacterial community structure, due to the creation of nutrient-rich hotspots in soils, which increased the relative abundance of the microorganisms.

Under artificial soil conditions, Ding et al. [181] investigated the influence of clay minerals (montmorillonite and illite), metal oxides (ferrihydrite and gibbsite) and charcoal on soil bacterial communities and observed that montmorillonite and illite significantly influenced Bacteria and Beta proteobacteria, while a weak influence of metal oxides on Beta proteobacteria was obtained. Contrary to enhancing microbial communities and activity, clay minerals have also been reported to inhibit the growth and activity (respiration) of soil microorganisms [195] [200] [203] [204] [205]. For example, Wong et al. [204] observed that clay minerals (notably bentonite and kaolinite) have the potentials to inhibit the sulphate-reducing ability of Desulfovibrio vulgaris in sediments, and proposed that such inhibition might be due to the direct effect of $\mathrm{Al}^{3+}$ on the bacteria. Also, Rong et al. [200] observed that kaolinite and montmorillonite inhibited sporulation of Bacillus thuringiensis, while goethite hindered sporulation and significantly depressed the total metabolic activity of the bacterium. Lavie and Stotzky 
[203] reported that kaolinite, montmorillonite and polygorskite reduced the rate of respiration of Histoplasma capsulatum, through mechanisms of adhesion with mycelial surface which interfere with the movement of nutrients, metabolites, and gases across the mycelia wall. Details of the different mechanisms of bacterial adhesion by clay minerals have been reported in other studies [206] [207] [208] [209] Savage. Most recently, it has been demonstrated that structural $\mathrm{Fe}$ (II) from the reduction of Fe (III) in clay minerals (such as nontronite) appears to be the primary source of $\cdot \mathrm{OH}$ radical, which causes the death of some microorganisms.

\section{Conclusions and Future Challenges}

This study sought to demonstrate how clay minerals influence soil fertility and plant growth through its direct impacts on soil physical, chemical and biological properties. The relevant literature that has been selected and discussed in this work indicates that studies on the physical and chemical properties of clay minerals are not only of academic or theoretical interest, but have immense practical applications in soil fertility management and crop production. Based on the literature review presented in this work, state-of-the-art information concerning the subject matter is hereby succinctly presented. First of all, mechanisms of nutrient retention, release and availability have been well documented in the literature, yet are not completely understood. Most of these mechanisms involve adsorption-desorption and dissolution-precipitation processes. Secondly, mechanisms of SOM retention and stabilization by clay minerals have also been well documented but are not definite. Notwithstanding, it is probable that mechanisms leading to the formation of short-range-ordered phases [123], which act as regulators of soil C storage, form the basis for understanding SOM retention by clay minerals. Besides this mechanism another commonly acceptable means of SOM stabilization involves organo-Fe complex formation or tertiary associations among iron oxides, $\mathrm{OM}$ and other soil minerals, which overrules sorption mechanisms that were generally accepted in earlier studies. As concerns the influence of clay minerals on $\mathrm{N}, \mathrm{P}$ and $\mathrm{K}$ retention and availability in soil, a vast majority of studies have been directed towards $\mathrm{K}$ nutrition, followed by $\mathrm{P}$ and lastly N. Furthermore, clay minerals affect soil physical properties primarily through the formation of microaggregates, which in turn influence nutrient availability and plant growth. In fact, it has been established that the most important role of clay minerals vis-à-vis soil fertility, is the formation of microaggregates. With regards to soil acidification, a soil's $\mathrm{pH}$ as influenced by clay minerals is a rather straight forward concept, this as a result of the nature of different clay minerals (i.e. either basic or acidic) within particular environments. Based on knowledge about nutrient sequestration by clay minerals, recent advances have been made in promoting nutrient availability and uptake through the use of nutrient-solubilizing microorganisms, especially $\mathrm{K}$ and $\mathrm{P}$.

For future research, it will be imperative that clay mineralogy and soil biology 
be given equal weight when conducting soil fertility studies. This automatically requires the need for developing expertise in the both disciplines. Given that mineralogical analyses are indispensable in soil fertility investigations and for developing effective fertilizer recommendation systems, the major challenge for scientists is the development of rapid, low-cost, reliable and efficient techniques of soil mineralogical analysis directly applicable to soil fertility investigations and management. Future research should also investigate mineralogical factors that will favour the sequestration and quantification of soil $\mathrm{N}$ across different climatic gradients and ecosystems, in a similar way to the great interest that had been directed towards carbon. This could be very helpful not only in sustaining soil health and crop production, but also contribute in mitigating climate change. Additionally, there is need to understand how changes in mineralogy will affect nutrient budgets and how these changes can influence soil testing methods and their interpretations. Also, it is our desire that this overview stimulates expert research that can develop quantitative correlations among clay minerals, soil fertility attributes and plant growth such that a more simplified and clearer image is discerned.

Lastly, clay minerals should find a place within the concept of soil quality. Soil quality is a very important concept in soil science and was established in an attempt to balance multiple soil uses with goals for environmental quality [210]. Unfortunately, the concept has been a source of division among soil scientists due to its many weaknesses and contradictions [211], especially when it comes to the choice of soil quality indicators and methodologies used for establishing soil quality indices. In most studies that have attempted to define soil quality and establish soil quality indices [212] [213] [214] [215], it is unfortunate that clay minerals have been overlooked. This is probably because most desirable soil quality indicators are those attributes that are most sensitive to management [216]. Given that clay minerals have a great role to play in different soil ecological functions, they need to be considered and incorporated within soil quality indicators. As already observed in soil science, this task must incorporate the joint efforts of different research fields such as interfacial and colloid chemistry, clay mineralogy, soil science, plant physiology and soil ecology.

\section{Conflicts of Interest}

The authors declare no conflicts of interest regarding the publication of this paper.

\section{References}

[1] Buresh, R.J., Sanchez, P.A. and Calhoun, F. (1997) Replenishing Soil Fertility in Africa. SSSA Special Publication 51, SSSA and ASA, Madison, WI, 252.

[2] Roy, R.N., Finck, A., Blair, G.J. and Tandon, H.L.S. (2006) Plant Nutrition for Food Security. A Guide for Integrated Nutrient Management. FAO Fertilizer and Plant Nutrition Bulletin 16. Food and Agricultural Organization of United Nations, Rome, 348. 
[3] Badraoui, M., Soudi, B., Moujahid, Y., Bennani, F., Bouhlassa, S. and Mikou, M. (1997) Mineralogical Consideration in Soil Fertility Management in Morocco. In: Ryan, J., Ed., Accomplishments and Future Challenges in Dry Land Soil Fertility Research in the Mediterranean Area, Proc. of the Soil Fertility Workshop, November 1995, ICARDA, Aleppo, Syria.

[4] Voortman, R.L., Sonneveld, B.G.J.S. and Keyzer, M.A. (2003) African Land Ecology: Opportunities and Constraints for Agricultural Development. AMBIO, 32, 367-373. https://doi.org/10.1579/0044-7447-32.5.367

[5] Nyambura, K.M. (2013) Characterization of Soil Mineralogy in Relation to Soil Fertility Functional Properties for Selected Countries in Africa. Master's Thesis, Kenyatta University, Kahawathe, Kenya.

[6] Karathanasis, A.D. (2006) Soil Mineralogy. Land Use and Land Cover, from Encyclopedia of Life Support Systems (EOLSS), Developed under the Auspices of the UNESCO. EOLSS Publishers, Oxford, UK.

[7] Barton, C.D. and Karathanasis, A.D. (2002) Clay Minerals. In: Lal, R., Ed., Encyclopedia of Soil Science, Marcel Dekker, New York, USA, 187-192.

[8] Wilson, M.J. (1999) The Origin and Formation of Clay Minerals in Soils: Past, Present and Future Perspectives. Clay Minerals, 34, 7-25. https://doi.org/10.1180/000985599545957

[9] Churchman, G.J. and Lowe, D.J. (2012) Alteration, Formation, and Occurrence of Minerals in Soils. In: Huang, P.M., Li, Y. and Sumner, M.E., Eds., Handbook of Soil Science. Properties and Processes, 2nd Edition, CRC Press, Taylor \& Francis, Boca Raton, 172.

[10] Mandiringana, O.T., Mnkeni, P.N.S., Mkile, Z., van Averbeke, W., Van Ranst, E. and Verplancke, H. (2005) Mineralogy and Fertility Status of Selected Soils of the Eastern Cape Province, South Africa. Communications in Soil Science and Plant Analysis, 36, 2431-2446. https://doi.org/10.1080/00103620500253514

[11] Abe, S.S., Masunaga, T., Yamamoto, S., Honna, T. and Wakatsuki, T. (2006) Comprehensive Assessment of the Clay Mineralogical Composition of Lowland Soils in West Africa. Soil Science and Plant Nutrition, 52, 479-488. https://doi.org/10.1111/j.1747-0765.2006.00060.x

[12] Blanco-Canqui, H. and Lal, R. (2008) Principles of Soil Conservation and Management. Springer, Berlin, 564.

[13] Yerima, B.P.K. and Van Ranst, E. (2005) Introduction to Soil Science: Soils of the Tropics. Trafford Publishing, Canada, 397.

[14] Scherer, H.W., Feils, E. and Beuters, P. (2014) Ammonium Fixation and Release by Clay Minerals as Influenced by Potassium. Plant, Soil and Environment, 60, 325-331. https://doi.org/10.17221/202/2014-PSE

[15] Li, T., Wang, H., Wang, J., Zhou, Z. and Zhou, J. (2015) Exploring the Potential of Phyllosilicate Minerals as Potassium Fertilizers Using Sodium Tetraphenylboron and Intensive Cropping with Perennial Ryegrass. Scientific Reports, 5, Article No. 9249. https://doi.org/10.1038/srep09249

[16] Moterle, D.F., Kaminski, J., dos Santos, R.D., Caner, L. and Bortoluzzi, E.C. (2016) Impact of Potassium Fertilization and Potassium Uptake by Plants on Soil Clay Mineral Assemblage in South Brazil. Plant and Soil, 406, 157-172. https://doi.org/10.1007/s11104-016-2862-9

[17] Kim, R.Y., Yoon, J.K., Kim, T.S., Yang, J.E., Owens, G. and Kim, K.R. (2015) Bioavailability of Heavy Metals in Soils: Definitions and Practical Implementation-A 
Critical Review. Environmental Geochemistry and Health, 37, 1041-1061. https://doi.org/10.1007/s10653-015-9695-y

[18] Goh, K.J. (2004) Fertilizer Recommendation Systems for Oil Palm: Estimating the Fertilizer Rates. In: Soon, C.P. and Pau, T.Y., Eds., Proceedings of MOSTA Best Practices Workshops. Agronomy and Crop Management, Malaysian Oil Scientists and Technologies Association, Kuala Lampur, 235-268.

[19] Bar-Yosef, B., Magen, H., Johnston, A.E. and Kirkby, E.A. (2015) Potassium Fertilization: Paradox or K Management Dilemma? Renewable Agriculture and Food Systems, 30, 115-119. https://doi.org/10.1017/S1742170514000295

[20] Jaiswal, D.K., Verma, J.P., Prakash, S., Meena, V.S. and Meena, R.S. (2016) Potassium as an Important Plant Nutrient in Sustainable Agriculture: A State of the Art. In: Meena, V.S., Maurya, B.R., Prakash Verma, J. and Meena, R.S., Eds., Potassium Solubilizing Microorganisms for Sustainable Agriculture, Springer, New Delhi, 21-29. https://doi.org/10.1007/978-81-322-2776-2 2

[21] Conti, M.E., de la Horra, A.M., Effron, D. and Zourarakis, D. (2001) Factors Affecting Potassium Fixation in Argentine Agricultural Soils. Communications in Soil Science and Plant Analysis, 32, 2679-2690. https://doi.org/10.1081/CSS-120000954

[22] Bühmann, C., Escott, B.J. and Hughes, J.C. (2004) Soil Mineralogy Research in South Africa, 1978 to 2002-A Review. South African Journal of Plant and Soil, 21, 316-329. https://doi.org/10.1080/02571862.2004.10635067

[23] Shepherd, K.D. and Walsh, M.G. (2007) Infrared Spectroscopy-Enabling an Evidence-Based Diagnostic Surveillance Approach to Agricultural and Environmental Management in Developing Countries. Journal of Near Infrared Spectroscopy, 15, 1-19. https://doi.org/10.1255/jnirs.716

[24] Karathanasis, A.D. (1985) Mineralogy and Soil Productivity. Agronomy Notes, 18, 1-4.

[25] Sparks, D.L. (2003) Environmental Soil Chemistry. Academic Press, Elsevier Science, Cambridge, MA.

[26] Jones, J.B. (2012) Plant Nutrition and Soil Fertility Manual. 2nd Edition, CRC Press, Taylor \& Francis Group, Boca Raton, FL, 273. https://doi.org/10.1201/b11577

[27] Sparks, D.L. (2018) Kinetics and Mechanisms of Chemical Reactions at the Soil Mineral/Water Interface. In: Sparks, D.L., Ed., Soil Physical Chemistry, 2nd Edition, CRC Press, Boca Raton, FL, 135-192.

[28] Barker, V.A. and Pilbeam, J.D. (2007) Handbook of Plant Nutrition. CRC Press, Taylor and Francis Group, Boca Raton, FL.

[29] Manning, D.A.C. (2010) Mineral Sources of Potassium for Plant Nutrition. A Review. Agronomy for Sustainable Development, 30, 281-294. https://doi.org/10.1051/agro/2009023

[30] Sollins, P., Robertson, G.P. and Uehara, G. (1988) Nutrient Mobility in Variableand Permanent-Charge Soils. Biogeochemistry, 6, 181-199.

https://doi.org/10.1007/BF02182995

[31] Dotaniya, M.L., Meena, V.D., Basak, B.B. and Meena, R.S. (2016) Potassium Uptake by Crops as Well as Microorganisms. In: Meena, V.S., Maurya, B.R., Prakash Verma, J. and Meena, R.S., Eds., Potassium Solubilizing Microorganisms for Sustainable Agriculture, Springer, New Delhi, 267-280. https://doi.org/10.1007/978-81-322-2776-2 19

[32] Yadav, B.K. and Sidhu, A.S. (2016) Dynamics of Potassium and Their Bioavailability for Plant Nutrition. In: Meena, V.S., Maurya, B.R., Prakash Verma, J. and Meena, 
R.S., Eds., Potassium Solubilizing Microorganisms for Sustainable Agriculture, Springer, New Delhi, 187-201. https://doi.org/10.1007/978-81-322-2776-2 14

[33] Uehara, G. and Gillman, G.P. (1981) The Mineralogy, Chemistry, and Physics of Tropical Soils with Variable Charge Clays. Westview Tropical Agriculture Series No. $4,170$.

[34] Qafoku, N.P., Van Ranst, E., Noble, A. and Baert, G. (2004) Variable Charge Soils: Their Mineralogy, Chemistry and Management. Advances in Agronomy, 84, 159-215. https://doi.org/10.1016/S0065-2113(04)84004-5

[35] Delgado, A. and Gómez, J.A. (2016) The Soil. Physical, Chemical and Biological Properties. In: Villalobos, F.J. and Fereres, E., Eds., Principles of Agronomy for Sustainable Agriculture, Springer, Cham, 15-26.

https://doi.org/10.1007/978-3-319-46116-8 2

[36] Berg, B. (2000) Litter Decomposition and Organic Matter Turnover in Northern Forest Soils. Forest Ecology and Management, 133, 13-22. https://doi.org/10.1016/S0378-1127(99)00294-7

[37] Dahlgren, R.A. (1994) Soil Acidification and Nitrogen Saturation from Weathering of Ammonium-Bearing Rock. Nature, 368, 838-841. https://doi.org/10.1038/368838a0

[38] Strathouse, S.M., Sposito, G., Sullivan, P.J. and Lund, L.J. (1980) Geologic Nitrogen, a Potential Geochemical Hazard in the San Joaquin Valley, California. Journal of Environmental Quality, 9, 54-60. https://doi.org/10.2134/jeq1980.00472425000900010014x

[39] Morford, S.L., Houlton, B.Z. and Dahlgren, R.A. (2011) Increased Forest Ecosystem Carbon and Nitrogen Storage from Nitrogen Rich Bedrock. Nature, 477, 78-81. https://doi.org/10.1038/nature10415

[40] Schuur, E.A.G. (2011) Nitrogen from the Deep. Nature, 477, 39-40. https://doi.org/10.1038/477039a

[41] Houlton, B.Z. and Morford, S.L. (2015) A New Synthesis for Terrestrial Nitrogen Inputs. Soil, 1, 381-397. https://doi.org/10.5194/soil-1-381-2015

[42] Jilling, A., Keiluweit, M., Contosta, A.R., Frey, S., Schimel, J., Schnecker, J., Smith, R.G., Tiemann, L. and Grandy, A.S. (2018) Minerals in the Rhizosphere: Overlooked Mediators of Soil Nitrogen Availability to Plants and Microbes. Biogeochemistry, 139, 103-122. https://doi.org/10.1007/s10533-018-0459-5

[43] Lehmann, J., Lilienfein, J., Rebel, K., do Carmo Lima, S. and Wilcke, W. (2004) Subsoil Retention of Organic and Inorganic Nitrogen in a Brazilian Savanna Oxisol. Soil Use and Management, 20, 163-172.

[44] Rasiah, V. and Armour, J.D. (2001) Nitrate Accumulation under Cropping in the Ferralsols of Far North Queensland Wet Tropics. Australian Journal of Soil Research, 39, 329-341. https://doi.org/10.1071/SR99133

[45] Kothawala, D.N. and Moore, T.R. (2009) Adsorption of Dissolved Nitrogen by Forest Mineral Soils. Canadian Journal of Forest Research, 39, 2381-2390. https://doi.org/10.1139/X09-147

[46] Donn, M.J., Menzies, N.W. and Rasiah, V. (2004) Chemical Characterisation of Deep Profile Ferrosols under Sugarcane in Wet Tropical Northern Queensland. Australian Journal of Soil Research, 42, 69-77. https://doi.org/10.1071/SR03052

[47] Holloway, J.M. and Dahlgren, R.A. (2002) Nitrogen in Rock: Occurrences and Biogeochemical Implications. Global Biogeochemical Cycles, 16, 1118-1135. https://doi.org/10.1029/2002GB001862 
[48] Nieder, R., Dinesh, K.B. and Scherer, H.W. (2011) Fixation and Defixation of Ammonium in Soils: A Review. Biology and Fertility of Soils, 47, 1-14. https://doi.org/10.1007/s00374-010-0506-4

[49] Mamo, M., Taylor, R.W. and Shuford, J.W. (1993) Ammonium Fixation by Soil and Pure Clay Minerals. Communications in Soil Science and Plant Analysis, 24, 1115-1126. https://doi.org/10.1080/00103629309368864

[50] Stevenson, F.J. and Cole, M.A. (1999) Cycles of Soil: Carbon, Nitrogen, Phosphorus, Sulfur, Micronutrients. 2nd Edition, Wiley, New York, 448.

[51] Sahrawat, K.L. (1979) Ammonium Fixation in Some Tropical Rice Soils. Communications in Soil Science and Plant Analysis, 10, 1015-1023. https://doi.org/10.1080/00103627909366958

[52] Gouveia, G. and Eudoxi, G. (2002) Relationship between Ammonium Fixation and Some Soil Properties and Effect of Cation Treatment on Fixed Ammonium Release in a Range of Trinidad Soils. Communications in Soil Science and Plant Analysis, 33, 1751-1765. https://doi.org/10.1081/CSS-120004820

[53] Sanchez, C.A. (2007) Phosphorus. In: Barker, V.A. and Pilbeam, J.D., Eds., Handbook of Plant Nutrition, CRC Press, Taylor \& Francis Group, Boca Raton, FL, 51-90.

[54] Fink, J.R., Inda, A.V., Bavaresco, J., Barrón, V., Torrent, J. and Bayer, C. (2016) Phosphorus Adsorption and Desorption in Undisturbed Samples from Subtropical Soils under Conventional Tillage or No-Tillage. Journal of Plant Nutrition and Soil Science, 179, 198-205. https://doi.org/10.1002/jpln.201500017

[55] Bajwa, M.I. (1981) Soil Clay Mineralogies in Relation to Fertility Management: Effect of Soil Clay Mineral Compositions on Phosphorus Fixation under Conditions of Wetland Rice Culture. Communications in Soil Science and Plant Analysis, 12, 475-482. https://doi.org/10.1080/00103628109367167

[56] Redel, Y., Cartes, P., Demanet, R., Velásquez, G., Poblete-Grant, P., Bol R. and Mora, M.L. (2016) Assessment of Phosphorus Status Influenced by $\mathrm{Al}$ and Fe Compounds in Volcanic Grassland Soils. Journal of Soil Science and Plant Nutrition, 16, 490-506. https://doi.org/10.4067/S0718-95162016005000041

[57] Vistoso, E., Theng, B.K.G., Bolan, N.S., Parfitt, R.L. and Mora, M.L. (2012) Competitive Sorption of Molybdate and Phosphate in Andisols. Journal of Soil Science and Plant Nutrition, 12, 59-72. https://doi.org/10.4067/S0718-95162012000100006

[58] Stutter, M., Stand, C., George, T., Blackwell, M., Dixon, L., Bol, R., MacKay, R., Richardson, A., Condron, L. and Haygarth, P. (2015) Land Use and Soil Factors Affecting Accumulation of Phosphorus Species in Temperate Soils. Geoderma, 257-258, 29-39. https://doi.org/10.1016/j.geoderma.2015.03.020

[59] Clarholm, M., Skyllberg, U. and Rosling, A. (2015) Organic Acid Induced Release of Nutrients from Metal-Stabilized Soil Organic Matter-The Unbutton Model. Soil Biology and Biochemistry, 84, 168-176. https://doi.org/10.1016/j.soilbio.2015.02.019

[60] Mengel, K. (2007) Potassium. In: Barker, V.A. and Pilbeam, J.D., Eds., Handbook of Plant Nutrition, CRC Press, Taylor \& Francis Group, Boca Raton, FL, 91-120.

[61] Fageiria, N.K. (2015) Potassium. In: Barker, V.A. and Pilbeam, J.D., Eds., Handbook of Plant Nutrition, 2nd Edition, CRC Press, Taylor \& Francis Group, Boca Raton, FL, 127-163.

[62] Ramezanpour, H., Esmaeilnejad, L. and Akbarzadeh, A. (2010) Influence of Soil Physical and Mineralogical Properties on Erosion Variations in Marlylands of Southern Guilan Province, Iran. International Journal of Physical Sciences, 5, 365-378. 
[63] Khan, S.A., Mulvaney, R.L. and Ellsworth, T.R. (2014) The Potassium Paradox: Implications for Soil Fertility, Crop Production and Human Health. Renewable Agriculture and Food Systems, 29, 3-27. https://doi.org/10.1017/S1742170513000318

[64] Bajwa, M.I. (1981) Soil Clay Mineralogy in Relation to Fertility Management: Effect of Soil Clay Mineral Composition on Potassium Fixation under Conditions of Upland Rice Soils. Fertilizer Research, 2, 193-197. https://doi.org/10.1007/BF01834812

[65] Raheb, A. and Heidari, A. (2012) Effects of Clay Mineralogy and Physicochemical Properties on Potassium Availability under Soil Aquic Conditions. Journal of Soil Science and Plant Nutrition, 12, 747-761. https://doi.org/10.4067/S0718-95162012005000029

[66] Binner, I., Dultz, S., Schellhorn, M. and Schenk, M.K. (2017) Potassium Adsorption and Release Properties of Clays in Peat-Based Horticultural Substrates for Increasing the Cultivation Safety of Plants. Applied Clay Science, 145, 28-36. https://doi.org/10.1016/j.clay.2017.05.013

[67] Ghiri, M.N., Abtahi, A., Karimian, N., Owliaie, H.R. and Khormali, F. (2011) Kinetics of Non-Exchangeable Potassium Release as a Function of Clay Mineralogy and Soil Taxonomy in Calcareous Soils of Southern Iran. Archives of Agronomy and Soil Science, 57, 343-363. https://doi.org/10.1080/03650340903440144

[68] Ghiri, M.N. and Abtahi, A. (2012) Factors Affecting Potassium Fixation in Calcareous Soils of Southern Iran. Archives of Agronomy and Soil Science, 58, 335-352. https://doi.org/10.1080/03650340.2010.507194

[69] Shuman, L.M. (1991) Chemical Forms of Micronutrients in Soils. In: Mortvedt, J.J., Cox, F.R., Shuman, L.M. and Welch, R.M., Eds., Micronutrients in Agriculture, 2nd Edition, Soil Science Society of America, Madison, WI, 113-144.

[70] Brown, P.H. (2007) Nickel. In: Barker, V.A. and Pilbeam, J.D., Eds., Handbook of Plant Nutrition, CRC Press, Taylor \& Francis Group, Boca Raton, FL, 395-409.

[71] Wimmer, M.A., Goldberg, S. and Gupta, U.C. (2015) Boron. In: Barker, V.A. and Pilbeam, J.D., Eds., Handbook of Plant Nutrition, 2nd Edition, CRC Press, Taylor \& Francis Group, Boca Raton, FL, 306-332.

[72] Gupta, U.C. (2007) Boron. In: Barker, V.A. and Pilbeam, J.D., Eds., Handbook of Plant Nutrition, CRC Press, Taylor \& Francis Group, Boca Raton, FL, 242-277.

[73] Adriano, D.C. (2000) Trace Elements in the Terrestrial Environment. Biogeochemistry, Bioavailability, and Risks of Metals. 2nd Edition, Springer, New York, 866.

[74] Srivastiva, P.C. and Gupta, U.C. (1996) Trace Elements in Crop Production. Science Publishers, Labanon, 356.

[75] Redd, K.J., Munn, L.C. and Wang, L. (1997) Chemistry and Mineralogy of Molybdenum in Soils. In: Gupta, U.C., Ed., Soils and Plant Molybdenum and Its Significance in Crops and Livestock, Cambridge University Press, Cambridge, UK, 4-22. https://doi.org/10.1017/CBO9780511574689.003

[76] Goldberg, S., Forster, H.S. and Godfrey, C.L. (1996) Molybdenum Adsorption on Oxides, Clay Minerals, and Soils. Soil Science Society of America Journal, 60, 425-432. https://doi.org/10.2136/sssaj1996.03615995006000020013x

[77] McBride, M.B. (1994) Environmental Chemistry of Soils. Oxford University Press, New York, 406.

[78] Evangelou, V.P. (1998) Environmental Soil and Water Chemistry: Principles and Applications. John Wiley and Sons, New York, 564.

[79] Singh, B. and Schulze, D.G. (2015) Soil Minerals and Plant Nutrition. Nature Education Knowledge, 6, 1-10. 
[80] Kumar, M. and Babel, A.L. (2011) Available Micronutrient Status and Their Relationship with Soil Properties of Jhunjhunu Tehsil, District Jhunjhunu, Rajasthan, India. Thai Journal of Agricultural Science, 3, 97-106. https://doi.org/10.5539/jas.v3n2p97

[81] Mortvedt, J.J. (2000) Bioavailability of Micronutrients. In: Sumner, M.E., Ed., Handbook of Soil Science, CRC Press, Boca Raton, FL, 2148.

[82] Kabata-Pendias, A. and Pendias, H. (2001) Trace Elements in Soils and Plants. 3rd Edition, CRC Press, Boca Raton, FL, 413. https://doi.org/10.1201/9781420039900

[83] Yu, S., He, Z.L., Huang, C.Y., Chen, G.C. and Calvert, D.V. (2002) Adsorption-Desorption Behavior of Copper at Contaminated Levels in Red Soils from China. Journal of Environmental Quality, 31, 1129-1136. https://doi.org/10.2134/jeq2002.1129

[84] Montenegro, A.C., Ferreyroa, G.V., Parolo, M.E., Tudino, M.B., Lavado, R.S. and Molina, F.V. (2015) Copper Speciation in Soil: Time Evolution and Effect of Clay Amendment. Water, Air, \& Soil Pollution, 226, 293. https://doi.org/10.1007/s11270-015-2569-1

[85] Dai, J., Wang, W., Wu, W., Gao, J. and Dong, C. (2017) Adsorption and Desorption of $\mathrm{Cu}^{2+}$ on Paddy Soil Aggregates Pretreated with Different Levels of Phosphate. Journal of Environmental Sciences, 55, 311-320. https://doi.org/10.1016/j.jes.2016.06.037

[86] Silva-Yumi, J., Escudey, M., Gacitua, M. and Pizarro, C. (2018) Kinetics, Adsorption and Desorption of $\mathrm{Cd}(\mathrm{II})$ and $\mathrm{Cu}(\mathrm{II})$ on Natural Allophane: Effect of Iron Oxide Coating. Geoderma, 319, 70-79. https://doi.org/10.1016/j.geoderma.2017.12.038

[87] Duxbury, J.M., Smith, M.S., Doran, J., Jordan, C., Szott, L. and Vance, E. (1989) Soil Organic Matter as a Source and Sink of Plant Nutrients. In: Coleman, D.C., Oades, M. and Uehara, G., Eds., Dynamics of Soil Organic Matter in Tropical Ecosystems, NifTAL Press, Maui, HI, 33-67.

[88] Allison, F.E. (1973) Soil Organic Matter and Its Role in Crop Production. Elsevier, Amsterdam, 637.

[89] Lehmann, J. and Kleber, M. (2015) The Contentious Nature of Soil Organic Matter. Nature, 528, 60-68. https://doi.org/10.1038/nature16069

[90] Paustian, K., Six, J., Elliot, E.T. and Hunt, H.W. (2000) Management Options for Reducing $\mathrm{CO}_{2}$ Emissions from Agricultural Soils. Biogeochemistry, 48, 147-163. https://doi.org/10.1023/A:1006271331703

[91] Wattel-Koekkoek, E.J.W., van Genuchten, P.P.L., Buurman, P. and van Lagen, B. (2001) Amount and Composition of Clay-Associated Soil Organic Matter in a Range of Kaolinitic and Smectitic Soils. Geoderma, 99, 27-49. https://doi.org/10.1016/S0016-7061(00)00062-8

[92] Bingham, A.H. and Cotrufo, M.F. (2016) Organic Nitrogen Storage in Mineral Soil: Implications for Policy and Management. Science of the Total Environment, 551-552, 116-126. https://doi.org/10.1016/j.scitotenv.2016.02.020

[93] Masiello, C.A., Chadwick, O.A., Southon, J., Torn, M.S. and Harden, J.W. (2004) Weathering Controls on Mechanisms of Carbon Storage in Grassland Soils. Global Biogeochemical Cycles, 18, 1-9. https://doi.org/10.1029/2004GB002219

[94] Scott, E. and Rothstein, D.E. (2014) The Dynamic Exchange of Dissolved Organic Matter Percolating through Six Diverse Soils. Soil Biology and Biochemistry, 69, 83-92. https://doi.org/10.1016/j.soilbio.2013.10.052

[95] Merino, C., Nannipieri, P. and Matus, F. (2015) Soil Carbon Controlled by Plant, 
Microorganism and Mineralogy Interactions. Journal of Soil Science and Plant Nutrition, 15, 321-332. https://doi.org/10.4067/S0718-95162015005000030

[96] Ashton, N.J., Tye, A.M., Pattrick, R.A.D. and van Dongen, B.E. (2016) Carbon Sequestration in the Soils of Northern Ireland: Potential Based on Mineralogical Controls. In: Young, M.E., Ed., Unearthed: Impacts of the Tellus Surveys of the North of Ireland, Royal Irish Academy, Dublin, Ireland, 373-385.

[97] Laird, D.A., Martens, D.A. and Kingery, W.L. (2001) Nature of Clay-Humic Complexes in an Agricultural Soil: I. Chemical, Biochemical and Spectroscopic Analyses. Soil Science Society of America Journal, 65, 1413-1418. https://doi.org/10.2136/sssaj2001.6551413x

[98] Yu, B., Dong, H., Iang, H.J., Guo, L.V., Eberl, D., Li, S. and Kim, J. (2009) The Role of Clay Minerals in the Preservation of Organic Matter in Sediments of Qinghai Lake, NW China. Clays and Clay Minerals, 57, 213-226.

https://doi.org/10.1346/CCMN.2009.0570208

[99] Kiem, R., Knicker, H. and Kögel-Knabner, I. (2002) Refractory Organic Carbon in Particle-Size Fractions of Arable Soils. I: Distribution of Refractory Carbon between the Size Fractions. Organic Geochemistry, 33, 1683-1697.

https://doi.org/10.1016/S0146-6380(02)00113-4

[100] Six, J., Conant, R.T., Paul, E.A. and Paustian, K. (2002) Stabilization Mechanisms of Soil Organic Matter: Implications for C-Saturation of Soils. Plant and Soil, 241, 155-176. https://doi.org/10.1023/A:1016125726789

[101] Kiem, R. and Kögel-Knabner, I. (2003) Contribution of Lignin and Polysaccharides to the Refractory Carbon Pool in C-Depleted Arable Soils. Soil Biology and Biochemistry, 35, 101-118. https://doi.org/10.1016/S0038-0717(02)00242-0

[102] Carter, M., Angers, D.A., Gregorich, E.G. and Bolinder, M.A. (2003) Characterizing Organic Matter Retention for Surface Soils in Eastern Canada Using Density and Particle Size Fractions. Canadian Journal of Soil Science, 83, 11-23. https://doi.org/10.4141/S01-087

[103] Christensen, B.T. (1992) Physical Fractionation of Soil and Organic Matter in Primary Particle Size and Density Separates. In: Stewart, B.A., Eds., Advances in Soil Science. Advances in Soil Science, Vol. 20, Springer, New York, 1-90. https://doi.org/10.1007/978-1-4612-2930-8 1

[104] Cheshire, M.V., Dumat, C., Fraser, A.R., Hiller, S. and Staunton, S. (2000) The Interaction between Soil Organic Matter and Soil Clay Minerals by Selective Removal and Controlled Addition of Organic Matter. European Journal of Soil Science, 51, 497-509. https://doi.org/10.1111/j.1365-2389.2000.00325.x

[105] Puget, P., Chenu, C. and Balesdent, J.B. (2000) Dynamics of Soil Organic Matter Associated with Particle-Size Fractions of Water-Stable Aggregates. European Journal of Soil Science, 51, 595-605.

https://doi.org/10.1111/j.1365-2389.2000.00353.x

[106] Six, J., Elliott, E.T. and Paustian, K. (2000) Soil Macroaggregate Turnover and Microaggregate Formation: A Mechanism for C Sequestration under No-Tillage Agriculture. Soil Biology and Biochemistry, 32, 2099-2103.

https://doi.org/10.1016/S0038-0717(00)00179-6

[107] Krull, E.S., Baldock, J.A. and Skjemstad, J.O. (2003) Importance of Mechanisms and Processes of the Stabilisation of Soil Organic Matter for Modelling Carbon Turnover. Functional Plant Biology, 30, 207-222. https://doi.org/10.1071/FP02085

[108] Zinn, Y.L., Lal, R. and Resck, D.V.S. (2005) Changes in Soil Organic Carbon Stocks under Agriculture in Brazil. Soil \& Tillage Research, 84, 28-40. 
https://doi.org/10.1016/j.still.2004.08.007

[109] Churchman, G.J. (2018) Game Changer in Soil Science. Functional Role of Clay Minerals in Soil. Journal of Plant Nutrition and Soil Science, 181, 99-103. https://doi.org/10.1002/jpln.201700605

[110] Totsche, K.U., Amelung, W., Gerzabek, M.H., Guggenberger, G., Klumpp, E., Knief, C., Lehndorff, E., Mikutta, R., Peth, S., Prechtel, A., Ray, N. and Kogel-Knabner, I. (2018) Microaggregates in Soils. Journal of Plant Nutrition and Soil Science, 181, 104-136. https://doi.org/10.1002/jpln.201600451

[111] Wattel-Koekkoek, E.J.W., Buurman, P., van der Pflicht, J., Wattel, E. and van Breemen, N. (2003) Mean Residence Time of Soil Organic Matter Associated with Kaolinite and Smectite. European Journal of Soil Science, 54, 269-278.

https://doi.org/10.1046/j.1365-2389.2003.00512.x

[112] Jindaluang, W., Kheoruenromne, I., Suddhiprakarn, A., Singh, B.P. and Singh, B. (2010) Relationships between Mineralogical Properties and Carbon and Nitrogen Retention in Upland Soils of Thailand. 19th World Congress of Soil Science, Soil Solutions for a Changing World, Brisbane, Australia, 1-6 August 2010.

[113] Kaiser, K. and Guggenberger, G. (2003) Mineral Surfaces and Soil Organic Matter. European Journal of Soil Science, 54, 219-236. https://doi.org/10.1046/j.1365-2389.2003.00544.x

[114] Wiseman, C.L.S. and Püttmann, W. (2005) Soil Organic Carbon and Its Sorptive Preservation in Central Germany. European Journal of Soil Science, 56, 65-76. https://doi.org/10.1111/j.1351-0754.2004.00655.x

[115] Wiseman, C.L.S. and Püttmann, W. (2006) Interaction between Mineral Phases in the Preservation of Soil Organic Matter. Geoderma, 134, 109-118. https://doi.org/10.1016/j.geoderma.2005.09.001

[116] Zeraatpische, M. and Khormali, F. (2012) Carbon Stock and Mineral Factors Controlling Soil Organic Carbon in a Climatic Gradient, Golestan Province. Journal of Soil Science and Plant Nutrition, 12, 637-654. https://doi.org/10.4067/S0718-95162012005000022

[117] Curtin, D. (2002) Possible Role of Aluminium in Stabilizing Organic Matter in Particle Size Fractions of Chermozemic and Solonetzic Soils. Canadian Journal of Soil Science, 82, 265-268. https://doi.org/10.4141/S01-035

[118] Kaiser, K., Eusterhues, K., Rumpel, C., Guggenberger, G. and Kogel-Knabner, I. (2002) Stabilization of Organic Matter by Soil Minerals-Investigations of Density and Particle-Size Fractions from Two Acid Forest Soils. Journal of Plant Nutrition and Soil Science, 165, 451-459. https://doi.org/10.1002/1522-2624(200208)165:4<451::AID-JPLN451>3.0.CO;2-B

[119] Yerima, B.P.K. and Van Ranst, E. (2005) Major Soil Classification Systems Used in the Tropics: Soils of Cameroon. Trafford Publishing, Canada, 282.

[120] Singh, M., Sarkar, B., Biswas, B., Bolan, N.S. and Churchman, G.J. (2017) Relationship between Soil Clay Mineralogy and Carbon Protection Capacity as Influenced by Temperature and Moisture. Soil Biology and Biochemistry, 109, 95-106. https://doi.org/10.1016/j.soilbio.2017.02.003

[121] Wagai, R. and Mayer, L.M. (2007) Sorptive Stabilization of Organic Matter in Soils by Hydrous Iron Oxides. Geochimica et Cosmochimica Acta, 71, 25-35. https://doi.org/10.1016/j.gca.2006.08.047

[122] Schulten, H.R. and Leinweber, P. (2000) New Insights into Organic-Mineral Particles: Composition, Properties and Models of Molecular Structure. Biology and 
Fertility of Soils, 30, 399-432. https://doi.org/10.1007/s003740050020

[123] Yu, G., Xiao, J., Hu, S., Polizzotto, M.L., Zhao, F., McGrath, S.P., Li, H., Ran, W. and Shen, Q. (2017) Mineral Availability as a Key Regulator of Soil Carbon Storage. Environmental Science \& Technology, 51, 4960-4969. https://doi.org/10.1021/acs.est.7b00305

[124] Hernandez-Soriano, M., Dalal, R., Warren, F.J., Wang, P., Green, K., Tobin, M.J., Menzies, N.W. and Kopittke, P.M. (2018) Soil Organic Carbon Stabilization: Mapping Carbon Speciation from Intact Microaggregates. Environmental Science \& Technology, 52, 12275-12284. https://doi.org/10.1021/acs.est.8b03095

[125] Osman, K.T. (2013) Physical Properties of Forest Soils. In: Forest Soils, Springer, Cham, 19-44. https://doi.org/10.1007/978-3-319-02541-4 2

[126] Nagy, N.M. and Konia, J. (2010) Interfacial Chemistry of Rocks and Soil. CRC Press, Taylor \& Francis Group, Boca Raton, FL, 229.

[127] Powers, J.S. and Schlesinger, W.H. (2002) Relationships among Soil Carbon Distributions and Biophysical Factors at Nested Spatial Scales in Rain Forests of Northeastern Costa Rica. Geoderma, 109, 165-190. https://doi.org/10.1016/S0016-7061(02)00147-7

[128] Krause, L., Rodionov, A., Schweizer, S.A., Siebers, N., Lehndorff, E., Klumpp, E. and Amelung, W. (2018) Microaggregate Stability and Storage of Organic Carbon Is Affected by Clay Content in Arable Luvisols. Soil \& Tillage Research, 182, 123-129. https://doi.org/10.1016/j.still.2018.05.003

[129] Kleber, M., Eusterhues, K., Keiluweit, M., Mikutta, C., Mikutta, R. and Nico, P.S. (2015) Mineral-Organic Associations: Formation, Properties, and Relevance in Soil Environments. Advances in Agronomy, 130, 1-140. https://doi.org/10.1016/bs.agron.2014.10.005

[130] Asano, M. and Wagai, R. (2014) Evidence of Aggregate Hierarchy at Micro- to Submicron Scales in an Allophanic Andisol. Geoderma, 216, 62-74. https://doi.org/10.1016/j.geoderma.2013.10.005

[131] Chenu, C. and Plante, A.F. (2006) Clay-Sized Organo-Mineral Complexes in a Cultivation Chronosequence: Revisiting the Concept of the "Primary Organo-Mineral Complex". European Journal of Soil Science, 57, 596-607. https://doi.org/10.1111/j.1365-2389.2006.00834.x

[132] Garland, G., Bünemann, E.K., Oberson, A., Frossard, E., Snapp, S., Chikowo, R. and Six, J. (2018) Phosphorus Cycling within Soil Aggregate Fractions of a Highly Weathered Tropical Soil: A Conceptual Model. Soil Biology and Biochemistry, 116, 91-98. https://doi.org/10.1016/j.soilbio.2017.10.007

[133] Siebers, N., Bauke, S.L., Tamburini, F. and Amelung, W. (2018) Short-Term Impacts of Forest Clear-Cut on P Accessibility in Soil Microaggregates: An Oxygen Isotope Study. Geoderma, 315, 59-64. https://doi.org/10.1016/j.geoderma.2017.11.024

[134] Nelson, P.N., Baldock, J.A., Clarke, P., Oades, J.M. and Churchman, G.J. (1999) Dispersed Clay and Organic Matter in Soil: Their Nature and Associations. Australian Journal of Soil Research, 37, 289-316. https://doi.org/10.1071/S98076

[135] Gaiser, T., Graef, F. and Cordeiro, J.C. (2000) Water Retention Characteristics of Soils with Contrasting Clay Mineral Composition in Semi-Arid Tropical Regions. Australian Journal of Soil Research, 38, 523-536. https://doi.org/10.1071/SR99001

[136] Tiwari, B. and Marui, H. (2005) A New Method for the Correlation of Residual Shear Strength of the Soil with Mineralogical Composition. Journal of Geotechnical 
and Geoenvironmental Engineering, 131, 1139-1150.

https://doi.org/10.1061/(ASCE)1090-0241(2005)131:9(1139)

[137] Moghimi, A.H., Hamdan, J., Shamshuddin, J., Samsuri, A.W. and Abtahi, A. (2012) Mineralogy and Aggregate Stability of Soils in the Arid Region of Southeastern Iran. African Journal of Agricultural Research, 7, 1639-1649.

[138] Heshmati, M., Majid, N.M., Jusop, S., Gheitury, M. and Abdu, A. (2013) Effects of Soil and Rock Mineralogy on Soil Erosion Features in the Merek Watershed, Iran. Journal of Geographic Information System, 5, 248-257. https://doi.org/10.4236/jgis.2013.53024

[139] Fontes, M.P.F. and Alleoni, L.R.F. (2006) Electrochemical Attributes and Availability of Nutrients, Toxic Elements, and Heavy Metals in Tropical Soils. Scientia Agricola, 63, 589-605. https://doi.org/10.1590/S0103-90162006000600014

[140] Tan, K.H. (2011) Principles of Soil Chemistry. Taylor \& Francis Group, Boca Raton, FL, 362.

[141] Husson, O. (2013) Redox Potential (Eh) and pH as Drivers of Soil/Plant/Microorganism Systems: A Transdisciplinary Overview Pointing to Integrative Opportunities for Agronomy. Plant and Soil, 362, 389-417. https://doi.org/10.1007/s11104-012-1429-7

[142] Glenn, A. and Dilworth, M. (1991) Soil Acidity and the microbial population: survival and Growth of Bacteria in Low pH. In: Wright, R.J., Ed., Plant-Soil Interactions at Low pH, Kluwer Academic, Boston, MA, 567-579. https://doi.org/10.1007/978-94-011-3438-5 64

[143] Fageria, N.K. and Baligar, V.C. (2003) Fertility Management of Tropical Acid Soils for Sustainable Crop Production. In: Rengel, Z., Ed., Handbook of Soil Acidity, Marcel Deker, Inc., New York, 359-385.

[144] Rengasamy, P. (2016) Soil Chemistry Factors Confounding Crop Salinity Tolerance-A Review. Agronomy, 6, 53. https://doi.org/10.3390/agronomy6040053

[145] Sanchez, P. (1976) Properties and Management of Soils in the Tropics. John Wiley \& Sons, New York, 618.

[146] Beinroth, F.H., Eswaran, H., Palmieri, F. and Reich, P.F. (1996) Properties, Classification and Management of Oxisols. U.S. Department of Agriculture, Natural Resources Conservation Service, Washington DC, 174.

[147] Ritchie, G.S.P. and Dolling, P.J. (1985) The Role of Organic Matter in Soil Acidification. Australian Journal of Soil Research, 23, 569-576. https://doi.org/10.1071/SR9850569

[148] McCauley, A., Jones, C. and Olson-Rutz, K. (2017) Soil pH and Organic Matter. Nutrient Management Module No. 8. Montana State University Extension, 16.

[149] Marschner, H. (1995) Adaptation of Plants to Adverse Chemical Soil Conditions. In: Mineral Nutrition of Higher Plants, 2nd Edition, Academic Press, London, 596-680. https://doi.org/10.1016/B978-012473542-2/50018-3

[150] Larssen, T., Vogt, R.D., Seip, H.M., Furoberg, G., Liao, B., Ziao, J. and Xiong, J. (1999) Mechanisms for Aluminium Release in Chinese Acid Forest Soils. Geoderma, 91, 65-86. https://doi.org/10.1016/S0016-7061(98)00131-1

[151] Foy, C.D., Duncan, R.R., Waskom, R.M. and Miller, D.R. (1993) Tolerance of Sorghum Genotypes to an Acid, Aluminum Toxic Tatum Subsoil. Journal of Plant Nutrition, 16, 97-127. https://doi.org/10.1080/01904169309364517

[152] Rout, G.R., Samantaray, S. and Das, P. (2001) Aluminium Toxicity in Plants: A Review. Agronomie, 21, 3-21.

[153] Gupta, N., Gaurav, S.S. and Kumar, A. (2013) Molecular Basis of Aluminium Tox- 
icity in Plants: A Review. American Journal of Plant Sciences, 4, 21-37. https://doi.org/10.4236/ajps.2013.412A3004

[154] Foy, C.D. (1984) Physiological Effects of Hydrogen, Aluminium and Manganese Toxicities in Acid Soils. In: Adams, F., Ed., Soil Acidity and Liming, 2nd Edition, American Society of Agronomy, Madison, WI, 57-97.

[155] Foy, C.D. (1992) Soil Chemical Factors Limiting Plant Root Growth. In: Hatfield, J.L. and Stewart, B.A., Eds., Advances in Soil Sciences: Limitations to Plant Root Growth, Springer Verlag, New York, 97-149. https://doi.org/10.1007/978-1-4612-2894-3 5

[156] Sanchez, P.A. and Logan, T.J. (1992) Myths and Science about the Chemistry and Fertility of Soils in the Tropics. In: Lal, R. and Sanchez, P.A., Eds., Myths and Science of Soils of the Tropics, SSSA Special Publication No. 29, 35-46.

[157] Iyamuremye, F. and Dick, R.P. (1996) Organic Amendments and Phosphorus Sorption by Soils. Advances in Agronomy, 56, 139-185. https://doi.org/10.1016/S0065-2113(08)60181-9

[158] Hopkins, B.G. (2015) Phosphorus. In: Barker, V.A. and Pilbeam, J.D., Eds., Handbook of Plant Nutrition, 2nd Edition, CRC Press, Taylor \& Francis Group, Boca Raton, FL, 65-126.

[159] Chintala, R., Schumacher, T.E., McDonald, L.M., Clay, D.E., Malo, D.D., Papiernik, S.K., Clay, D.E. and Julson, J.L. (2014) Phosphorus Sorption and Availability from Biochars and Soil/Biochar Mixtures. CLEAN-Soil, Air, Water, 42, 626-634. https://doi.org/10.1002/clen.201300089

[160] Bohn, H., McNeal, B. and O’Connor, G. (2001) Soil Chemistry. 3rd Edition, Wiley Inter-Science, New York, 206-259.

[161] Zhalnina, K., Dias, R., de Quadros, P.D., Davis-Richardson, A., Camargo, F.A., Clark, I.M., McGrath, S.P., Hirsch, P.R. and Triplett, E.W. (2015) Soil pH Determines Microbial Diversity and Composition in the Park Grass Experiment. Microbial Ecology, 69, 395-406. https://doi.org/10.1007/s00248-014-0530-2

[162] Magdoff, F. (2018) Soil Quality and Management. In: Agroecology, CRC Press, Boca Raton, FL, 349-364. https://doi.org/10.1201/9780429495465-18

[163] Bolan, N.S. (1991) A Critical Review on the Role of Mycorrhizal Fungi in the Uptake of Phosphorus by Plants. Plant and Soil, 134, 189-207.

https://doi.org/10.1007/BF00012037

[164] Milleret, R., Le Bayon, R.C. and Gobat, J.M. (2009) Root, Mycorrhiza and Earthworm Interactions: Their Effects on Soil Structuring Processes, Plant and Soil Nutrient Concentrations and Plant Biomass. Plant and Soil, 316, 1-12. https://doi.org/10.1007/s11104-008-9753-7

[165] Masood, S. and Bano, A. (2016) Mechanism of Potassium Solubilization in the Agricultural Soils by the Help of Soil Microorganisms. In: Meena, V.S., Maurya, B.R., Prakash Verma, J. and Meena, R.S., Eds., Potassium Solubilizing Microorganisms for Sustainable Agriculture, Springer, New Delhi, 137-147. https://doi.org/10.1007/978-81-322-2776-2 10

[166] Raghavendra, M.P., Nayaka, S.C. and Nuthan, B.R. (2016) Role of Rhizosphere Microflora in Potassium Solubilization. In: Meena, V.S., Maurya, B.R., Prakash Verma, J. and Meena, R.S., Eds., Potassium Solubilizing Microorganisms for Sustainable Agriculture, Springer, New Delhi, 43-59. https://doi.org/10.1007/978-81-322-2776-2 4

[167] Zahedi, H. (2016) Growth-Promoting Effect of Potassium-Solubilizing Microorgan- 
isms on Some Crop Species. In: Meena, V.S., Maurya, B.R., Prakash Verma, J. and Meena, R.S., Eds., Potassium Solubilizing Microorganisms for Sustainable Agriculture, Springer, New Delhi, 31-42. https://doi.org/10.1007/978-81-322-2776-2 3

[168] Meena, V.S., Bahadur, I., Maurya, B.R., Kumar, A., Meena, R.K., Meena, S.K. and Verma, J.P. (2016) Potassium-Solubilizing Microorganism in Evergreen Agriculture: An Overview. In: Meena, V.S., Maurya, B.R., Prakash Verma, J. and Meena, R.S., Eds., Potassium Solubilizing Microorganisms for Sustainable Agriculture, Springer, New Delhi, 1-20. https://doi.org/10.1007/978-81-322-2776-2_1

[169] Shrivastava, M., Srivastava, P.C. and D’Souza, S.F. (2016) KSM Soil Diversity and Mineral Solubilization in Relation to Crop Production and Molecular Mechanism. In: Meena, V.S., Maurya, B.R., Prakash Verma, J. and Meena, R.S., Eds., Potassium Solubilizing Microorganisms for Sustainable Agriculture, Springer, New Delhi, 221-234. https://doi.org/10.1007/978-81-322-2776-2 16

[170] Etesami, H., Emami, S. and Alikhani, H.A. (2017) Potassium Solubilizing Bacteria (KSB): Mechanisms, Promotion of Plant Growth, and Future Prospects-A Review. Journal of Soil Science and Plant Nutrition, 17, 897-911. https://doi.org/10.4067/S0718-95162017000400005

[171] Singh, J.S., Pandey, V.C. and Singh, D.P. (2011) Efficient Soil Microorganisms: A New Dimension for Sustainable Agriculture and Environmental Development. Agriculture, Ecosystems \& Environment, 140, 339-353.

https://doi.org/10.1016/j.agee.2011.01.017

[172] Bardgett, R.D., Usher, M.B. and Hopkins, D.W. (2005) Biological Diversity and Function in Soils. Cambridge University Press, Cambridge, UK, 428. https://doi.org/10.1017/CBO9780511541926

[173] Gadd, G.M. (2010) Metals, Minerals and Microbes: Geomicrobiology and Bioremediation. Microbiology, 156, 609-643. https://doi.org/10.1099/mic.0.037143-0

[174] Burghelea, C., Zaharescu, D.G., Dontsova, K., Maier, R., Huxman, T. and Chorover, J. (2015) Mineral Nutrient Mobilization by Plants from Rock: Influence of Rock Type and Arbuscular Mycorrhiza. Biogeochemistry, 124, 187-203. https://doi.org/10.1007/s10533-015-0092-5

[175] Kramer, S. and Green, D.M. (2000) Acid and Alkaline Phosphatase Dynamics and Their Relationship to Soil Microclimate in a Semiarid Woodland. Soil Biology and Biochemistry, 32, 179-188. https://doi.org/10.1016/S0038-0717(99)00140-6

[176] Zhou, J.Z., Xia, B.C., Treves, D.S., Wu, L.Y., Marsh, T.L., O’Neill, R.V., Palumbo, A.V. and Tiedje, J.M. (2002) Spatial and Resource Factors Influencing High Microbial Diversity in Soil. Applied and Environmental Microbiology, 68, 326-334. https://doi.org/10.1128/AEM.68.1.326-334.2002

[177] Fierer, N. and Jackson, R.B. (2006) The Diversity and Biogeography of Soil Bacterial Communities. Proceedings of the National Academy of Sciences of the United States of America, 103, 626-631. https://doi.org/10.1073/pnas.0507535103

[178] Stres, B., Danevcic, T., Pal, L., Fuka, M.M., Resman, L., Leskovec, S., Hacin, J., Stopar, D., Mahne, I. and Mandic-Mulec, I. (2008) Influence of Temperature and Soil Water Content on Bacterial, Archaeal and Denitrifying Microbial Communities in Drained Fen Grassland Soil Microcosms. FEMS Microbiology Ecology, 66, 110-122. https://doi.org/10.1111/j.1574-6941.2008.00555.x

[179] Lauber, C.L., Hamady, M., Knight, R. and Fierer, N. (2009) Pyrosequencing-Based Assessment of Soil $\mathrm{pH}$ as a Predictor of Soil Bacterial Community Structure at the Continental Scale. Applied and Environmental Microbiology, 75, 5111-5120. https://doi.org/10.1128/AEM.00335-09 
[180] Cho, S.J., Kim, M.H. and Lee, Y.O. (2016) Effect of pH on Soil Bacterial Diversity. Journal of Ecology and Environment, 40, Article No. 10. https://doi.org/10.1186/s41610-016-0004-1

[181] Ding, G.C., Pronk, G.J., Babin, D., Heuer, H., Heister, K., Kogel-Knabner, I. and Smalla, K. (2013) Mineral Composition and Charcoal Determine the Bacterial Community Structure in Artificial Soils. FEMS Microbiology Ecology, 86, 15-25. https://doi.org/10.1111/1574-6941.12070

[182] Birkhofer, K., Bezemer, T.M., Bloem, J., Bonkowski, M., Christensen, S., Dubois, D., Ekelund, F., Fliessbach, A., Gunst, L. and Hedlund, K. (2008) Long-Term Organic Farming Fosters Below and Aboveground Biota: Implications for Soil Quality, Biological Control and Productivity. Soil Biology and Biochemistry, 40, 2297-2308. https://doi.org/10.1016/j.soilbio.2008.05.007

[183] Wu, M., Qin, H., Chen, Z., Wu, J. and Wei, W. (2011) Effect of Long-Term Fertilization on Bacterial Composition in Rice Paddy Soil. Biology and Fertility of Soils, 47, 397-405. https://doi.org/10.1007/s00374-010-0535-Z

[184] Dong, W.Y., Zhang, X.Y., Dai, X.Q., Fu, X.L., Yang, F.T., Liu, X.Y., Sun, X.M., Wen, X.F. and Schaeffer, S. (2014) Changes in Soil Microbial Community Composition in Response to Fertilization of Paddy Soils in Subtropical China. Applied Soil Ecology, 84, 140-147. https://doi.org/10.1016/j.apsoil.2014.06.007

[185] Kaiser, K., Wemheuer, B., Korolkow, V., Wemheuer, F., Schöning, I., Schrump, M., Daniel, R. and Nacke, H. (2016) Driving Forces of Soil Bacterial Community Structure, Diversity, and Function in Temperate Grasslands and Forests. Scientific Reports, 6, Article No. 33696. https://doi.org/10.1038/srep33696

[186] Sessitsch, A., Weilharter, A., Kirchmann, H., Gerzabek, M.H. and Kandeler, E. (2001) Microbial Population Structures in Soil Particle Size Fractions of a Long-Term Fertilizer Field Experiment. Applied and Environmental Microbiology, 67, 4215-4224. https://doi.org/10.1128/AEM.67.9.4215-4224.2001

[187] Ramezanian, A., Campbell, C.D., Dahlin, S., Hillier, S. and Oborn, I. (2010) Relation of Soil Mineralogy and Microbial Communities Based on Micronutrient Status. 19th World Congress of Soil Science, Soil Solutions for a Changing World, Brisbane, Australia, 1-6 August 2010.

[188] Colombo, C., Palumbo, G., He, J.Z., Pinton, R. and Cesco, S. (2014) Review on Iron Availability in Soil: Interaction of Fe Minerals, Plants, and Microbes. Journal of Soils and Sediments, 14, 538-548. https://doi.org/10.1007/s11368-013-0814-Z

[189] Ahmad, M., Nadeem, S.M., Naveed, M. and Zahir, Z.A. (2016) Potassium-Solubilizing Bacteria and Their Application in Agriculture. In: Meena, V.S., Maurya, B.R., Prakash Verma, J. and Meena, R.S., Eds., Potassium Solubilizing Microorganisms for Sustainable Agriculture, Springer, New Delhi, 293-313. https://doi.org/10.1007/978-81-322-2776-2 21

[190] Teotia, P., Kumar, V., Kumar, M., Shrivastava, N. and Varma, A. (2016) Rhizosphere Microbes: Potassium Solubilization and Crop Productivity-Present and Future Aspects. In: Meena, V.S., Maurya, B.R., Prakash Verma, J. and Meena, R.S., Eds., Potassium Solubilizing Microorganisms for Sustainable Agriculture, Springer, New Delhi, 315-325. https://doi.org/10.1007/978-81-322-2776-2 22

[191] Terrazas, R.A., Giles, C., Paterson, E., Robertson-Albertyn, S., Cesco, S., Mimmo, T. and Bulgarelli, D. (2016) Plant-Microbiota Interactions as a Driver of the Mineral Turnover in the Rhizosphere. Advances in Applied Microbiology, 95, 1-67. https://doi.org/10.1016/bs.aambs.2016.03.001

[192] Filip, Z. (1973) Clay Minerals as a Factor Influencing Biochemical Activity of Soil 
Microorganisms. Folia Microbiologica, 18, 56-74. https://doi.org/10.1007/BF02884250

[193] Rosenzweig, W.D. and Stotzky, G. (1979) Influence of Environmental Factors on Antagonism of Fungi by Bacteria in Soil: Clay Minerals and pH. Applied and Environmental Microbiology, 38, 1120-1126.

[194] Dong, H. (2012) Clay-Microbe Interactions and Implications for Environmental Mitigation. Elements, 8, 113-118. https://doi.org/10.2113/gselements.8.2.113

[195] Wang, X., Dong, H., Zeng, Q., Xia, Q., Zhang, L. and Zhou, Z. (2017) Reduced Iron-Containing Clay Minerals as Antibacterial Agents. Environmental Science \& Technology, 51, 7639-7647. https://doi.org/10.1021/acs.est.7b00726

[196] Ransom, B., Bennett, R.H., Baerwald, R., Hulbert, M.H. and Burkett, P.J. (1999) In Situ Conditions and Interactions between Microbes and Minerals in Fine-Grained Marine Sediments: A TEM Microfabric Perspective. American Mineralogist, 84, 183-192. https://doi.org/10.2138/am-1999-1-220

[197] Kostka, J.E., Dalton, D.D., Skelton, H., Dollhop, S. and Stucki, J.W. (2002) Growth of Iron(III)-Reducing Bacteria on Clay Minerals as the Sole Electron Acceptor and Comparison of Growth Yields on a Variety of Oxidized Iron Forms. Applied and Environmental Microbiology, 68, 6256-6262. https://doi.org/10.1128/AEM.68.12.6256-6262.2002

[198] Lovley, D.R. and Phillips, E.J.P. (1988) Novel Mode of Microbial Energy Metabolism: Organic Carbon Oxidation Coupled to Dissimilatory Reduction of Iron or Manganese. Applied and Environmental Microbiology, 54, 1472-1480.

[199] Stotzky, G. and Rem, L.T. (1966) Influence of Clay Minerals on Microorganisms: I. Montmorillonite and Kaolinite on Bacteria. Canadian Journal of Microbiology, 12, 547-563. https://doi.org/10.1139/m66-078

[200] Rong, X., Huang, Q. and Chen, W. (2007) Microcalorimetric Investigation on the Metabolic Activity of Bacillus thuringiensis as Influenced by Kaolinite, Montmorillonite and Goethite. Applied Clay Science, 38, 97-103. https://doi.org/10.1016/j.clay.2007.01.015

[201] Courvoisier, E. and Dukan, S. (2009) Improvement of Escherichia coli Growth by Kaolinite. Applied Clay Science, 44, 67-70. https://doi.org/10.1016/j.clay.2009.01.010

[202] Carson, J.K., Campbell, L., Rooney, D., Clipson, N. and Gleeson, D.B. (2009) Minerals in Soil Select Distinct Bacterial Communities in Their Microhabitats. FEMS Microbiology Ecology, 67, 381-388. https://doi.org/10.1111/j.1574-6941.2008.00645.x

[203] Lavie, S. and Stotzky, G. (1986) Adhesion of the Clay Minerals Montmorillonite, Kaolinite, and Attapulgite Reduces Respiration of Histoplasma capsulatum. Applied and Environmental Microbiology, 51, 61-73.

[204] Wong, D., Suflita, J.M., McKinley, J.P. and Krumholz, L.R. (2004) Impact of Clay Minerals on Sulfate-Reducing Activity in Aquifers. Microbial Ecology, 47, 80-86. https://doi.org/10.1007/s00248-003-1021-z

[205] Morrison, K.D., Underwood, J.C., Metge, D.W., Eberl, D.D. and Williams, L.B. (2014) Mineralogical Variables That Control the Antibacterial Effectiveness of a Natural Clay Deposit. Environmental Geochemistry and Health, 36, 613-631. https://doi.org/10.1007/s10653-013-9585-0

[206] Savage, D.C. and Fletcher, M. (1985) Bacterial Adhesion: Mechanisms and Physiological Significance. Springer, New York, 476. https://doi.org/10.1007/978-1-4615-6514-7 
[207] Müller, B. (2015) Experimental Interactions between Clay Minerals and Bacteria: A Review. Pedosphere, 25, 799-810. https://doi.org/10.1016/S1002-0160(15)30061-8

[208] Tavanaee, M., Shirvani, M. and Bakhtiary, S. (2017) Adhesion of Pseudomonas putida onto Palygorskite and Sepiolite Clay Minerals. Geomicrobiology Journal, 34, 677-686. https://doi.org/10.1080/01490451.2016.1238982

[209] Ren, L.Y., Hong, Z.N., Liu, Z.D. and Xu, R.K. (2018) ATR-FTIR Investigation of Mechanisms of Bacillus subtilis Adhesion onto Variable-And Constant-Charge Soil Colloids. Colloids and Surfaces B: Biointerfaces, 162, 288-295. https://doi.org/10.1016/j.colsurfb.2017.11.067

[210] Karlen, D.L., Mausbach, M.J., Doran, J.W., Cline, R.G., Harris, R.F. and Schuman, G.E. (1997) Soil Quality: A Concept, Definition, and Framework for Evaluation. Soil Science Society of America Journal, 61, 4-10. https://doi.org/10.2136/sssaj1997.03615995006100010001x

[211] Letey, J., Sojka, R.E., Upchurch, D.R., Cassel, D.K., Olson, K.R., Payne, W.A., Petrie, S.E., Price, G.H., Reginato, R.J., Scott, H.D., Smethurst, P.J. and Triplett, G.B. (2003) Deficiencies in the Soil Quality Concept and Its Application. Journal of Soil and Water Conservation, 58, 180-187.

[212] Doran, J.W., Coleman, D.C., Bezdicek, D.F. and Stewart, B.A. (1994) Defining Soil Quality for a Sustainable Environment. Soil Science Society of America Special Publication No. 35, Soil Science Society of America and American Society of Agronomy, Madison, WI.

[213] Doran, J.W. and Jones, A.J. (1996) Methods for Assessing Soil Quality. Soil Science Society of America Special Publication, Vol. 49, Soil Science Society of America, Madison, WI, $410 \mathrm{p}$.

[214] Karlen, D.L., Ditzler, C.A. and Andrews, S.S. (2003) Soil Quality: Why and How? Geoderma, 114, 145-156. https://doi.org/10.1016/S0016-7061(03)00039-9

[215] Bünemann, E.K., Bongiorno, G., Bai, Z., Creamer, R.E., De Deyn, G., de Goede, R., Fleskens, L., Geissen, V., Kuyper, T.W., Mäder, P., Pulleman, M., Sukkel, W., van Groenigen, J.W. and Brussaard, L. (2018) Soil Quality-A Critical Review. Soil Biology and Biochemistry, 120, 105-125. https://doi.org/10.1016/j.soilbio.2018.01.030

[216] Arshad, M.A. and Martin, S. (2002) Identifying Critical Limits for Soil Quality Indicators in Agro-Ecosystems. Agriculture, Ecosystems \& Environment, 88, 153-160. https://doi.org/10.1016/S0167-8809(01)00252-3 